\title{
Influence of soil-structure interaction on seismic pounding between steel frame buildings considering the effect of infill panels
}

\author{
Hytham Elwardany $^{1} \cdot$ Ayman Seleemah $^{2} \cdot$ Robert Jankowski $^{3}$ (D) $\cdot$ Saher El-khoriby $^{2}$
}

Received: 14 May 2019 / Accepted: 22 August 2019 / Published online: 3 September 2019

(C) The Author(s) 2019

\begin{abstract}
The present research aims to study the influence of the soil-structure interaction (SSI) and existence or absence of masonry infill panels in steel frame structures on the earthquakeinduced pounding-involved response of adjacent buildings. The study was further extended to compare the pounding-involved behavior versus the independent behavior of structures without collisions, focusing much on dynamic behavior of single frames. The effect of SSI was analyzed by assuming linear springs and dashpots at the foundation level. The infill panels were modeled using equivalent diagonal compression struts. The steel frames were assumed to have elastic-plastic behavior with $1 \%$ linear strain hardening. The dynamic contact approach was utilized to simulate pounding between the adjacent buildings. Nonlinear finite element analysis was performed for two adjacent multi-story structures with four different configurations representing cases that can exist in reality. The seismic response of the studied cases generally emphasized that ignoring the soil flexibility and/or the contribution of the infill panels may significantly alter the response of adjacent structures. This may result in a false expectation of the seismic behavior of buildings exposed to structural pounding under earthquake excitation.
\end{abstract}

Keywords Structural pounding $\cdot$ Earthquakes $\cdot$ Steel frame buildings $\cdot$ Masonry infill panels $\cdot$ Soil-structure interaction

Robert Jankowski

jankowr@pg.edu.pl

Hytham Elwardany

drhythamelwardany@yahoo.com

Ayman Seleemah

seleemah@ @-eng.tanta.edu.eg

Saher El-khoriby

drsaher2012@yahoo.com

1 Faculty of Engineering, Delta University for Science and Technology, Mansoura, Egypt

2 Structural Engineering Department, Faculty of Engineering, Tanta University, Tanta, Egypt

3 Faculty of Civil and Environmental Engineering, Gdansk University of Technology, Gdansk, Poland 


\section{Introduction}

Earthquake-induced pounding between buildings has been a topic of intensive research for more than three decades. Different approaches were used in the numerical simulations concerning the phenomenon. Basic analyses were conducted using simplified single-degree-offreedom models of structures (see, for example, Anagnostopoulos 1988; Jankowski 2005; Naderpour et al. 2016; Miari et al. 2019). Other studies were carried out applying discrete multi-degree-of-freedom models with masses lumped at each floor level (see Anagnostopoulos and Spiliopoulos 1992; Maison and Kasai 1992; Karayannis and Favvata 2005a, b; Jankowski and Mahmoud 2016).

Further investigations concerned more accurate models of buildings. Abdel Raheem (2006) studied impacts between two adjacent moment resisting frames. Papadrakakis et al. (1996) employed finite element models of colliding structures, in which floors were modeled using single four-node plane stress elements while the behavior of walls was simulated by four linear beam-column elements. More detailed nonlinear finite element analyses of pounding between two adjacent structures were also conducted (see Sołtysik and Jankowski 2013; Jankowski and Mahmoud 2015). More recently, detailed nonlinear finite element analyses were carried out between three adjacent structures in series to study the effect of the reciprocal pounding on the behavior of each building (see El-Khoriby et al. 2015a, b; Jankowski et al. 2015).

Structural engineers often ignore the influence of soil flexibility in the seismic design. The consideration of fixed-base foundation may be logical in highly stiff soils, whereas in other cases, the flexibility of the soil causes reduction in the global stiffness of the structural system (Wakabayashi 1985) which leads to an increase in the deformation and the total damping due to radiation damping in the soil (Wolf 1985; Beskos et al. 1994). Minasidis et al. (2014) investigated the effect of the dynamic soil-structure interaction (SSI) on the inelastic behavior of steel frames under different near-fault seismic motions. The results reveal that the soil flexibility significantly affects the seismic behavior of the steel frames, it increased the maximum ratios of the inter-story drifts and decreased the floor accelerations.

Very limited number of investigations focused on the effect of coupling between the soil flexibility and the earthquake-induced pounding between adjacent buildings. Rahman et al. (2001) studied the influence of both SSI and structural pounding on two adjacent reinforced concrete structures with 6 and 12 stories. The mass-damper-spring system proposed by Mulliken and Karabalis (1998) was used to model the soil effect. The results showed that, the soil flexibility increases the pounding force at all levels. Chouw and Hao (2005) investigated the effect of the spatial distribution of the seismic excitation and the influence of the soil flexibility on the pounding-involved response of two adjacent bridge frames. The study indicated that ignoring the influence of the SSI may cause a wrong prediction of the behavior of colliding bridge girders. Chouw and Hao (2008) studied the effect of the SSI and spatial distribution of the ground excitation on bridge behavior incorporating collisions. The conclusion of the study emphasized that stiff base structures may be exposed to higher pounding forces as compared to those on flexible base. Mahmoud et al. (2013) studied the effect of the soil flexibility on pounding between two equal height adjacent buildings. The results indicated that the soil flexibility may significantly affect the pounding-involved response of the more flexible building. Madani et al. (2015) discussed the effects of the SSI on the inelastic response of adjacent steel structures with a number of stories varied between 3 and 12. The study showed that the SSI considerably increases the 
values of pounding forces and leads to collisions even for larger gap distances. Kharazian (2017) studied the influence of the SSI on pounding between 3 and 5 story RC structures. The results showed that SSI has significant influence on the pounding-involved structural response during earthquakes.

Li et al. (2017) studied the seismic pounding considering the structure-soil-structure interaction effect (SSSI) for a practical project considering pile foundation, box foundation and rigid foundation conditions. A three-dimensional finite element model was constructed utilizing ANSYS software. The results showed that pounding and SSSI effects worsen the adjacent buildings' conditions because pounding amplifies their shear responses and accelerations. Despite these limited studies described above, all other investigations, which were focused on earthquake-induced structural pounding, ignored the flexibility of the soil.

During the process of designing different types of frame structures, engineers often treat masonry infill panels as non-structural elements. Meanwhile, recent specifications and building codes emphasize the importance of considering the effect of infill panels, since it may have a considerable influence on the behavior of the structure under seismic excitation. In particular, FEMA 356 (2000) underlines that masonry infill walls should be treated as primary elements of the structural system.

A number of studies were focused on the influence of infill panels on the structural response during earthquakes (Zhang 2006; Nwofor 2012). Sanij and Alaghebandian (2012) carried out pushover analysis on masonry infilled frame by using three macro models in order to simulate the nonlinear response of infill panels. Pounding between two adjacent multi-story RC unequal height structures was investigated by Favvata et al. (2012) taking into account the contribution of infill panels modeled as equivalent diagonal struts according to FEMA 273 (1997). The influence of inelastic response of external beam-column joints on collisions between unequal height buildings with infill panels was also investigated by Favvata et al. (2009). Karayannis et al. (2011) studied the effect of external beam-column joints on the mechanics of collapse in multi-story structures using the equivalent diagonal strut model to simulate the behavior of infill panels. Favvata and Karayannis (2013) studied the influence of inter-story seismic pounding on the response of infilled RC structures under seismic excitation. A numerical analysis on the effect of masonry infills on the seismic response of RC structures was conducted by Demir and Sivri (2002). The results indicated that the existence of infill panels significantly modifies the general seismic performance of frame buildings by enhancing the integrity and stability of the frames. A technique for modeling the interface between infill and frame was proposed by Dorji and Thambiratnam (2009). The gap element was used as an interface element between the frame and masonry wall. Karayannis et al. (2005) analytically investigated and experimentally verified the effect of infill panels on the lateral response of RC frames. The experimental results indicated that the initial stiffness of infilled frames was considerably increased (by about 2.88 times), as compared to bare frames.

It should be underlined that the research available in the literature has been conducted to study separately either the SSI effects, or the infill effects, on the seismic pounding of adjacent buildings. According to the author's knowledge, no research has been devoted to cover both effects simultaneously. Therefore, the present research aims to study the effects of infill panels combined with the SSI effects on the earthquake-induced structural pounding between neighboring structures. Four different structural cases were utilized to simulate scenarios that may exist during construction stages of adjacent buildings. The study was further extended to compare the pounding-involved behavior versus the independent behavior of structures without collisions, focusing much on dynamic behavior of single frames. 


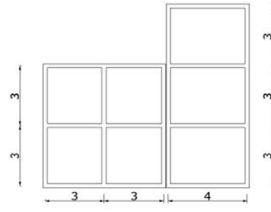

Case (1)

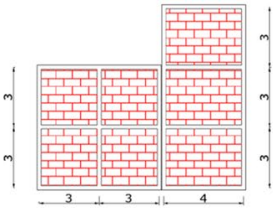

Case (2)

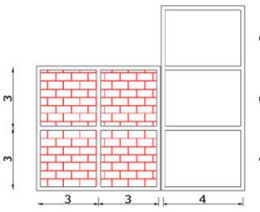

Case (3)

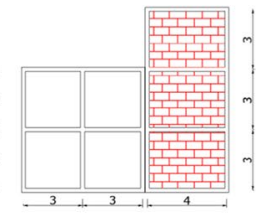

Case (4)

Fig. 1 Buildings under study

Table 1 Natural periods of different structures

\begin{tabular}{llllll}
\hline Structure & \multicolumn{2}{l}{ Natural period $(\mathrm{sec})$} & & \\
\cline { 2 - 3 } \cline { 5 - 6 } \cline { 5 - 6 } & Bare frame & & & \multicolumn{2}{l}{ Fully infilled frame } \\
\cline { 2 - 3 } \cline { 5 - 6 } Left building & 0.636 & 0.655 & & 0.101 & 0.1408 \\
Right building & 0.951 & 0.982 & & 0.170 & 0.253 \\
\hline
\end{tabular}

\section{Finite element model}

Two adjacent steel structures with $30 \mathrm{~mm}$ seismic gap and 5\% damping ratio were considered in the current study. While the structures were selected to simulate actual existing adjacent buildings, they were simplified to single-bay and two-bay multi-degree-of-freedom systems (see Fig. 1). It should be mentioned that the effect of pounding on the global seismic responses of adjacent structures is expected to be more severe when the vibration characteristics of the structures are quite different. Therefore, the masses and stiffness were adjusted to simulate the existing buildings with considerably different natural vibration periods. They were designed according to AISC 360-10 (2010) as well as UBC (1997) for $\mathrm{z}=0.15, \mathrm{R}=4.50$ and $\mathrm{I}=1.0$. The height of each story was $3.0 \mathrm{~m}$ for both buildings. The structures were composed of HSS139.7X4 steel sections. Each floor had $15 \mathrm{~cm}$ thickness concrete slab with weight of $0.35 \mathrm{t} / \mathrm{m}^{2}$. The concrete slabs were extended outside the structures by $1.0 \mathrm{~cm}$ to ensure that collisions occur between two concrete surfaces.

Four different cases of configurations were considered in the current analysis (see Fig. 1). Case (1) is the case of bare frames, where infill panels does not exist (this case represents buildings under construction). On the other hand, Case (2) represents the case of fully infilled frames. Moreover, Case (3) and Case (4) represent different arrangements of fully infilled and bare frame structures (they represent the case of a building under construction besides an existing fully infilled building). The influence of SSI on the poundinginvolved response was considered in the analysis. For comparison, the rigid foundation was also considered in all cases and modeled using the fixed base assumption. The modal analysis was conducted to obtain the natural vibration periods of the buildings under investigation (see Table 1).

ADINA (2010) software was utilized to carry out two-dimensional non-linear finite element analysis. The direct integration method was used to solve the dynamic equation of motion. Buildings under study were exposed to different earthquake records. Due to limitation of the space, the representative results for the chosen ground motion records are shown in this paper [first three ground motions listed in Table 2 for all cases and, additionally, two last ground motions listed in Table 2 for Case (4)]. It should be underlined that the selected 
Table 2 Ground motions used in the current study

\begin{tabular}{|c|c|}
\hline Ground motion & $\begin{array}{l}\text { Peak ground } \\
\text { acceleration } \\
\left(\mathrm{m} / \mathrm{s}^{2}\right)\end{array}$ \\
\hline El Centro 1940, NS & 3.070 \\
\hline Loma Prieta 1989, NS (Corralitos station) & 6.315 \\
\hline Northridge 1994, EW (Santa Monica station) & 8.660 \\
\hline Kobe 1995, NS (JMA station) ${ }^{\mathrm{a}}$ & 8.057 \\
\hline San Fernando $1971, \mathrm{~N}^{\circ} 4^{\circ} \mathrm{E}$ (Pacoima Dam station) ${ }^{\mathrm{a}}$ & 11.375 \\
\hline
\end{tabular}

${ }^{\text {a }}$ These records were used in solving Case (4) only

earthquake records possess different properties, such as peak ground acceleration, duration of strong motion and ranges of dominant frequencies, and therefore have different influences on structures.

The $\mathrm{P}-\Delta$ effect was considered in the analysis and the dynamic contact surface model was utilized to represent the pounding mechanism. In such mechanism, no connecting elements are used; only contactor surface and target one are defined (see ADINA 2010; Elwardany et al. 2017 as well as Bathe and Chaudhary 1985 for more details about the model). The model enables us to consider some local effects, such as inelastic flexural deformations, yield of the flexural reinforcement and ductility requirements of the columns adjacent to the pounding area (see also Jankowski and Mahmoud 2015 for more details about other possible ways of modeling of contact in problems of earthquake-induced structural pounding).

The material of the steel frames was assumed to behave as elastic-plastic with $1 \%$ linear strain hardening according to Eurocode 3 (2006) (see Fig. 2). The equivalent diagonal strut used by Elwardany et al. (2017) was utilized in the current study to simulate the effect of the infill panels (see Figs. 3, 4). Moreover, the properties of the masonry used by Sanij and Alaghebandian (2012) were also used in the current study (see Table 3).

The width of the compression strut was determined according to FEMA 356 (2000) and FEMA 273 (1997) as (see also Fig. 3)

$$
\mathrm{a}=0.175\left(\lambda_{1} \mathrm{~h}_{\mathrm{col}}\right)^{-0.4} \mathrm{r}_{\mathrm{inf}}
$$

Fig. 2 Stress-strain relationship of steel (ADINA 2010)

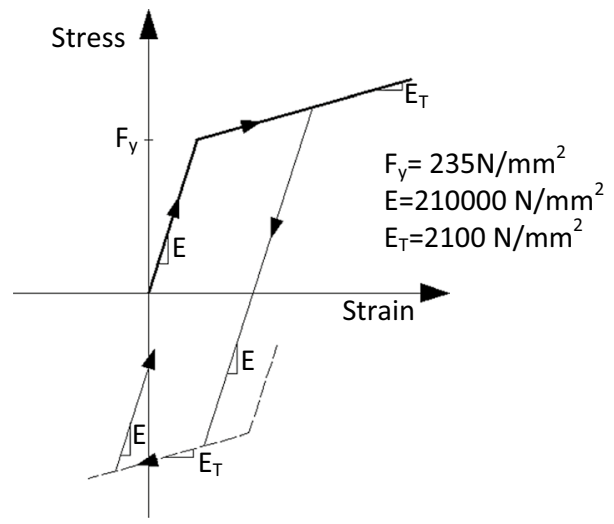


Fig. 3 Compression strut analogy-concentric struts

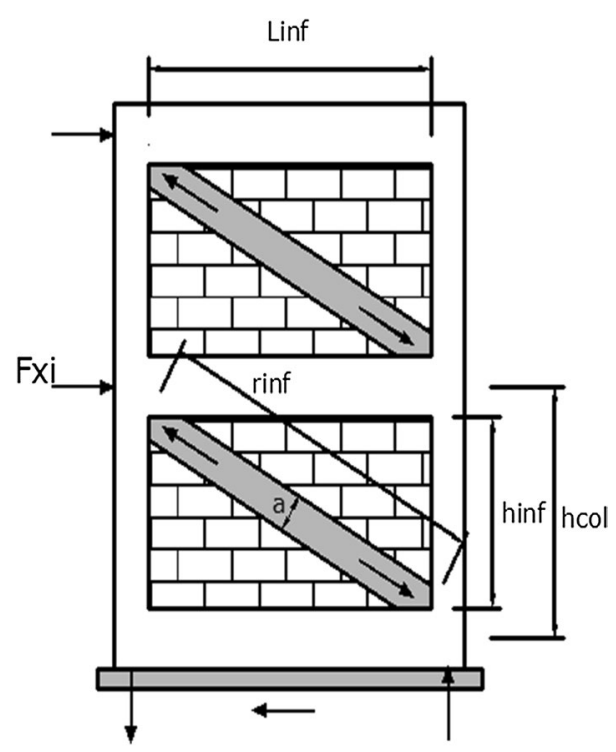

(b)

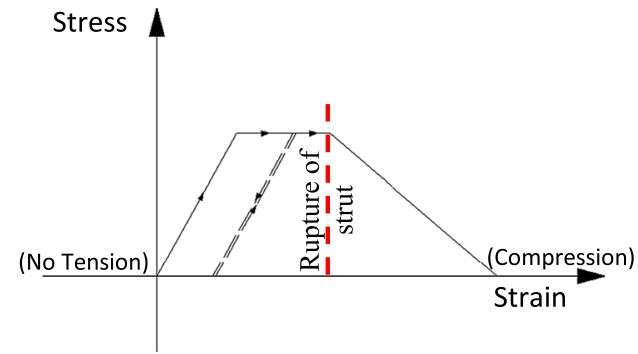

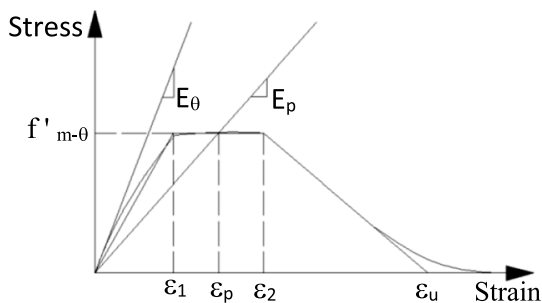

(a)

Fig. 4 a Simplified tri-linear stress-strain relation for masonry (El-Dakhakhni et al. 2004); b response of the equivalent strut

Table 3 Specifications of the masonry infill (see Sanij and Alaghebandian 2012)

\begin{tabular}{lll}
\hline Property & Symbol & Value (MPa) \\
\hline Masonry strength perpendicular to bed joints & $\mathrm{f}^{\prime}{ }_{\mathrm{m}-90}$ & 4.40 \\
Masonry strength parallel to bed joints & $\mathrm{f}^{\prime}{ }_{\mathrm{m}-0}$ & 3.08 \\
Young's modulus perpendicular to bed joints & $\mathrm{E}_{90}$ & 3300 \\
Shear modulus & $\mathrm{G}$ & 1320 \\
\hline
\end{tabular}

$$
\lambda_{1}=\left[\mathrm{E}_{\mathrm{me}} \mathrm{t}_{\mathrm{inf}} \sin 2 \theta / 4 \mathrm{E}_{\mathrm{fe}} \mathrm{I}_{\mathrm{col}} \mathrm{h}_{\mathrm{inf}}\right]^{0.25}
$$

where $h_{\text {col }}$ is the height of column between centerlines of beams; $h_{\text {inf }}$ is the height of the infill panel; $\mathrm{E}_{\mathrm{fe}}$ and $\mathrm{E}_{\mathrm{me}}$ are the expected Young's modulus of the frame and infill materials, respectively; $\mathrm{I}_{\text {col }}$ is the moment of inertia of the column; $\mathrm{L}_{\text {inf }}$ is the infill panel length; $\mathrm{r}_{\text {inf }}$ is the diagonal length of the infill panel; $t_{i n f}$ is the thickness of the infill panel; $\theta$ is the angle 
whose tangent is the infill height-to-length aspect ratio (in radians) and $\lambda_{1}$ is the coefficient used to determine equivalent width of infill strut.

In the lateral load case, the infill panel was considered to be diagonally loaded. Accordingly, the Young's modulus $\mathrm{E}_{\theta}$ of the panel in the diagonal direction was obtained using the constitutive relations of orthotropic plates and axes transformation matrix as (Shames and Cozzarelli 1997)

$$
\mathrm{E}_{\theta}=1 /\left[\cos ^{4} \theta / \mathrm{E}_{0}+\left[\left(-2 v_{0-90} / \mathrm{E}_{0}\right)+1 / \mathrm{G}\right] \cos ^{2} \theta \sin ^{2} \theta+\left(1 / \mathrm{E}_{90}\right) \sin ^{4} \theta\right]
$$

where $E_{0}$ is the Young's modulus in the direction parallel to bed joints and $v_{0-90}$ stands for the Poisson's ratio defined as the ratio of the strain in the direction normal to the bed joints and the strain in the direction parallel to the bed joints.

For masonry, the simplified tri-linear stress-strain relationship, shown in Fig. 4a, was used (for more details see El-Dakhakhni et al. 2004), where the secant Young's modulus at the peak load, $\mathrm{E}_{\mathrm{p}}$, can be calculated as

$$
\begin{gathered}
\mathrm{E}_{\mathrm{p}}=0.50 \mathrm{E}_{\theta} \\
\mathrm{f}_{\mathrm{m}-\theta}^{\prime}=\mathrm{E}_{\theta} / \alpha \\
\alpha=\mathrm{E}_{90} / \mathrm{f}_{\mathrm{m}-90}^{\prime}
\end{gathered}
$$

$\varepsilon_{\mathrm{p}}$ can be determined after obtaining $\mathrm{E}_{\mathrm{p}}$ and $\mathrm{f}_{\mathrm{m}-\theta}{ }^{\prime}$, where $\varepsilon_{1}$ and $\varepsilon_{2}$ can be determined from the following relations

$$
\begin{gathered}
\varepsilon_{1}=\varepsilon_{\mathrm{p}}-0.001 \\
\varepsilon_{2}=\varepsilon_{\mathrm{p}}+0.001
\end{gathered}
$$

where $\varepsilon_{\mathrm{u}}=0.01$.

The masonry infill was modeled in ADINA using the truss element with compression force only and the masonry tensile strength was ignored. Figure $4 \mathrm{~b}$ shows the response of the equivalent strut. When the strain in the strut reaches $\varepsilon_{2}$ (see Fig. 4a) the strut is assumed to rupture, the corresponding element is removed from the model and the degrading branch is ignored.

In the current study, a sandy clay soil was considered. According to Bowles (1997), the dynamic shear modulus equal to $20 \mathrm{MPa}$, the Poisson's ratio equal to 0.4 and the shear wave velocity, $V_{s}=100 \mathrm{~m} / \mathrm{sec}$ were considered. The shear wave velocity was estimated using the equation

where $\gamma=19 \mathrm{kN} / \mathrm{m}^{3}$.

$$
\mathrm{G}^{\prime}=\gamma \mathrm{V}_{\mathrm{s}}^{2} / \mathrm{g}
$$

The contribution of the soil flexibility was modeled using springs and dashpots (see Gazetas 1991; Mahmoud et al. 2013; Minasidis et al. 2014; Madani et al. 2015). The static stiffness of springs in each direction was firstly determined using the following equations developed by Gazetas (1991)

$$
\begin{gathered}
\mathrm{K}_{\mathrm{z}}=[2 \mathrm{GL} /(1-v)]\left(0.73+1.54 \mathrm{x}^{0.75}\right) \\
\mathrm{K}_{\mathrm{x}}=[2 \mathrm{GL} /(2-v)]\left(2+2.5 \mathrm{x}^{0.85}\right)-[0.2 /(0.75-v)] \mathrm{GL}[1-(\mathrm{B} / \mathrm{L})] \\
\mathrm{K}_{\mathrm{ry}}=[3 \mathrm{G} /(1-v)] \mathrm{I}_{\text {by }}^{0.75}(\mathrm{~L} / \mathrm{B})^{0.15}
\end{gathered}
$$


Table 4 Dynamic stiffness of soil springs and dashpots coefficients

\begin{tabular}{lll}
\hline Direction & Spring stiffness $(\mathrm{kN} / \mathrm{m})$ & $\begin{array}{l}\text { Dashpot } \\
\text { coefficients } \\
(\mathrm{kN} \mathrm{s} / \mathrm{m})\end{array}$ \\
\hline Vertical & $\mathrm{K}_{\mathrm{z}}=50,500$ & $\mathrm{C}_{\mathrm{z}}=355.18$ \\
$\begin{array}{l}\text { Horizontal } \\
\begin{array}{l}\text { Rocking (about the } \\
\text { lateral y-axis) }\end{array}\end{array}$ & $\mathrm{K}_{\mathrm{x}}=36,700$ & $\mathrm{C}_{\mathrm{r}}=235.65$ \\
\hline
\end{tabular}

where $x=A_{b} / 4 L^{2} ; A_{b}$ is the area of the foundation; $L$ is the foundation half-length; $B$ is the foundation half-width, $G$ is the shear modulus, $v$ is Poisson's ratio and $I_{b y}$ is the moment of inertia with relation to the lateral axes. Then, the dynamic stiffness of springs in each direction was calculated as the product of the static stiffness times the dynamic stiffness coefficient, as suggested by Gazetas (1991).

Damping was simulated using dashpots with the dashpot coefficient, C, calculated for both radiation and material damping generated in the system according to equation (Gazetas 1991)

$$
\text { Total } \mathrm{C}=\text { radiation } \mathrm{C}+2 \beta \mathrm{K}^{\prime} / \omega
$$

where the term $2 \beta \mathrm{K}^{\prime} / \omega$ is the material dashpot constant. The radiation dashpot coefficient, C, may be calculated for each direction as (Gazetas 1991)

$$
\begin{gathered}
\mathrm{C}_{\mathrm{z}}=\rho \mathrm{V}_{\mathrm{La}} \mathrm{A}_{\mathrm{b}} \mathrm{C}_{\mathrm{z}}^{\prime} \\
\mathrm{C}_{\mathrm{x}}=\rho \mathrm{V}_{\mathrm{s}} \mathrm{A}_{\mathrm{b}} \\
\mathrm{C}_{\mathrm{ry}}=\rho \mathrm{V}_{\mathrm{La}} \mathrm{I}_{\mathrm{by}} \mathrm{C}_{\mathrm{ry}}^{\prime} \\
\mathrm{V}_{\mathrm{La}}=[3.4 / \pi(1-v)] \mathrm{V}_{\mathrm{s}}
\end{gathered}
$$

where $\mathrm{C}_{\mathrm{z}}^{\prime}$ and $\mathrm{C}_{\mathrm{ry}}^{\prime}$ are the dimensionless damping factors, $\mathrm{V}_{\mathrm{s}}$ and $\mathrm{V}_{\mathrm{La}}$ are the velocity of the shear-wave and Lysmer's analog wave velocity. Table 4 lists the results obtained for the estimated parameters for the simulation of the soil flexibility for Northridge earthquake.

\section{Results and discussions}

\subsection{Independent vibrations of bare and fully infilled frames for rigid foundation and SSI cases}

To get an insight into the behavior of different structures, the analysis was performed considering the independent behavior of each building under different earthquakes with the assumption that no pounding occurs. For the bare frames (BF), considering the flexibility of the soil results in the slight increase in the natural periods of the buildings, as it can be seen from Table 1. It should be underlined in this place, however, that lengthening of the period of independently vibrating structures incorporating SSI is a well-known fact. Moreover, the general trend for the analyzed case of bare frames shows minor reduction in the peak acceleration for both buildings when the SSI is considered, as compared to the rigid base case (see Fig. 5). Moreover, considering the SSI slightly increases the peak displacement of the buildings and the maximum increase reaches about $15 \%$ at the 1 st floor of 

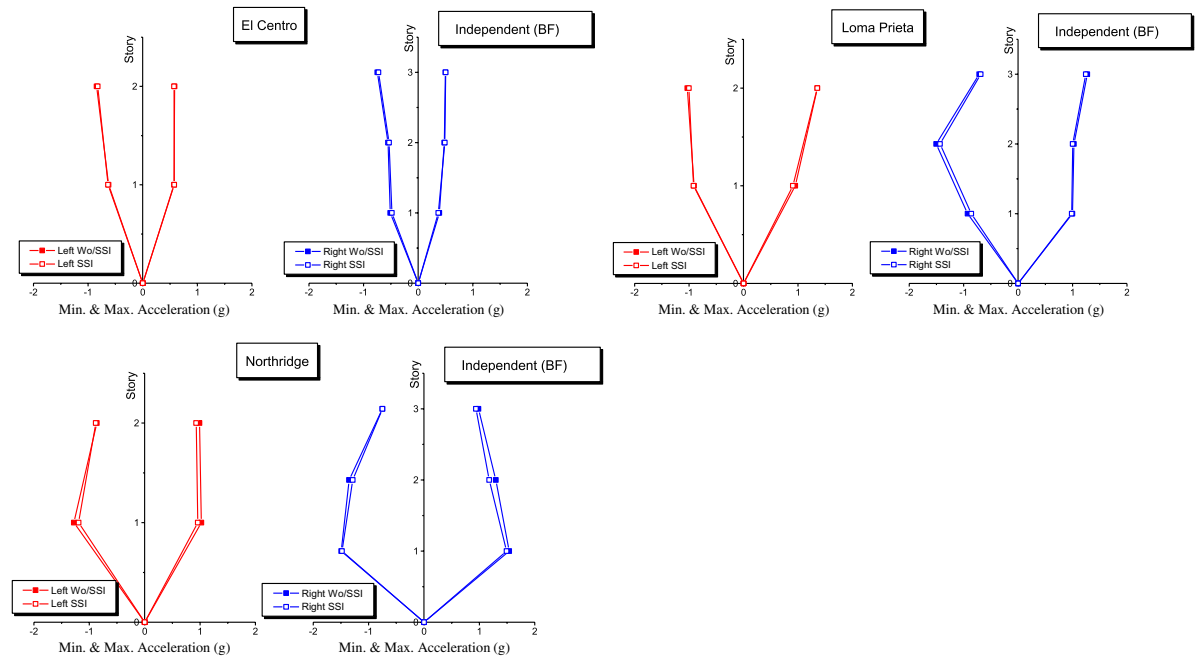

Fig. 5 Peak accelerations for the independent vibrations of the bare frames

the right building under the El Centro earthquake (see Fig. 6). Generally speaking, for bare frames, SSI causes minor increase in the displacement associated with minor reduction in the acceleration responses. This complies with NEHRP (2012) giving a relative measure for determining the SSI effects when they become significant. This relative measure is the structure-to-soil stiffness ratio, $\mathrm{h} /\left(\mathrm{V}_{\mathrm{s}} \mathrm{T}\right)$, where $\mathrm{h}$ is the effective height to the center of mass for the first mode shape which may be taken as two-thirds of the modeled building height; $\mathrm{V}_{\mathrm{s}}$ is the shear wave velocity and $\mathrm{T}$ is the fixed-based building period. It is stated that, if $\mathrm{h} /\left(\mathrm{V}_{\mathrm{s}} \mathrm{T}\right)>0.1$, SSI can significantly lengthen the building period and modify the distribution of forces and deformation demands within the structure. Applying this structure-tosoil stiffness ratio to the bare frame case, gives $\mathrm{h} /\left(\mathrm{V}_{\mathrm{s}} \mathrm{T}\right)=0.063$ which is less than 0.1 . It

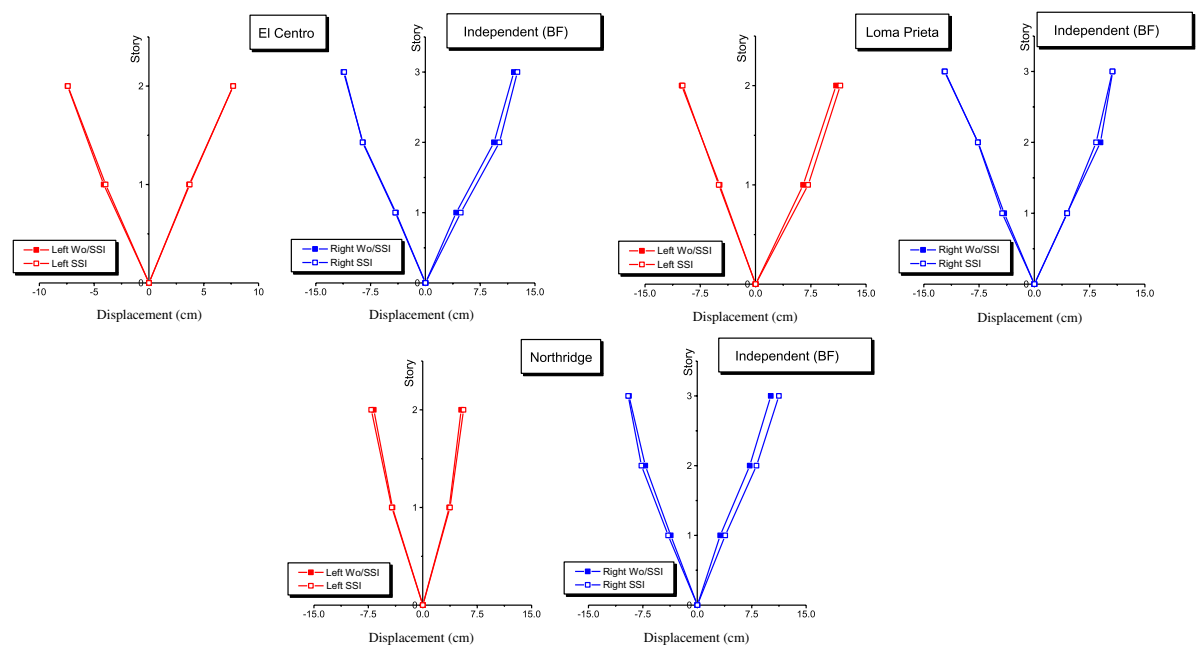

Fig. 6 Peak displacement for the independent vibrations of the bare frames 
means that no significant elongation of the building period will occur and consequently, no significant difference in the seismic behavior will take place. It should be emphasized that this criteria is valid only for the independent vibrations of buildings and the contribution of pounding may change this rule.

For the fully infilled frame (FI), taking the soil flexibility into account leads to the significant increase in the natural periods of buildings (see Table 1). This is in agreement with NEHRP (2012), as the value of $\mathrm{h} /\left(\mathrm{V}_{\mathrm{s}} \mathrm{T}\right)$ in this case is equal to 0.396 and 0.353 , for the left and right building, respectively, which is far greater than 0.1 . This greatly alters the seismic response of the independent vibrations of buildings. The change of the response due to SSI will depend on the location of the shifted period in the response spectrum curve of each specific earthquake. The maximum difference in the acceleration (equal to 88.15\%) is observed at the 3rd floor of the right building under the Loma Prieta earthquake (see Fig. 7).

Figure 8 shows the maximum displacement values for both buildings. The results show that, considering the SSI results in the significant increase in the peak displacements of both buildings under the three earthquakes. The maximum increase reaches about $139 \%$ at the 3rd floor of the right building under the Loma Prieta earthquake, whereas it reaches $79.55 \%$ at the 2 nd floor of the left building under the Northridge earthquake (see Fig. 8). It can be stated that for fully infilled frames, SSI causes moderate to significant increase in the peak displacement associated with minor to moderate increase or reduction in the peak acceleration with no specific trend, depending on location of the shifted period on the response spectrum curve.

Table 5 shows the maximum strains of the steel columns of the buildings under different earthquakes. In the case of bare frames, both buildings behave plastically when they vibrate independently. This is due to the large displacement values associated with the bare frames (refer to Fig. 6). Considering the SSI considerably affects the strains in the steel frame columns. The maximum increase reaches $16.62 \%$ for the right building under the El Centro earthquake, whereas the maximum reduction reaches $30.86 \%$ for the left structure under the El Centro earthquake. The maximum strain was observed in the left building

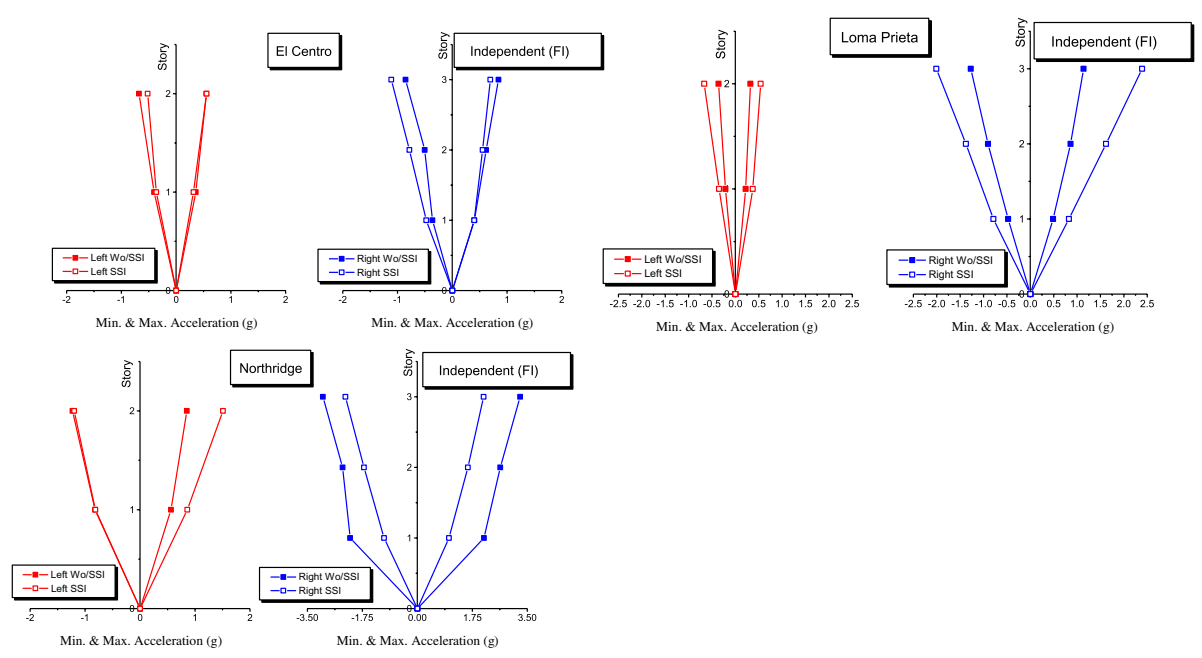

Fig. 7 Peak accelerations for the independent vibrations of the fully infilled frames 

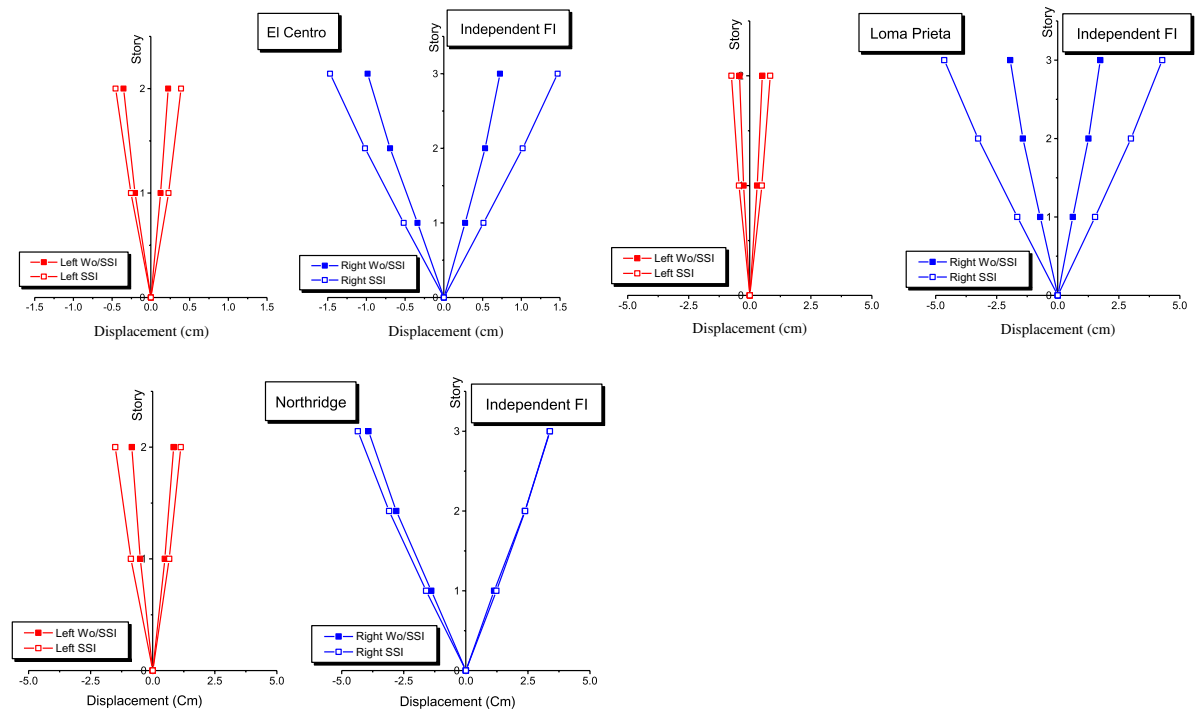

Fig. 8 Peak displacements for the independent vibrations of the fully infilled frames

Table 5 Maximum strains of the steel columns of the buildings under different earthquakes (independent vibrations case)

\begin{tabular}{|c|c|c|c|c|c|}
\hline \multirow[t]{3}{*}{ Earthquake } & \multirow[t]{3}{*}{ Structure } & \multicolumn{4}{|c|}{ Maximum strain $\left(\times 10^{-3}\right)$} \\
\hline & & \multicolumn{2}{|l|}{ Bare frame } & \multicolumn{2}{|c|}{ Fully infilled frame } \\
\hline & & Without SSI & With SSI & Without SSI & With SSI \\
\hline \multirow[t]{2}{*}{ El Centro } & Left building & 4.18 & 2.89 & 0.175 & 0.156 \\
\hline & Right building & 3.85 & 4.49 & 0.303 & 0.296 \\
\hline \multirow[t]{2}{*}{ Loma Prieta } & Left building & 10.6 & 10.7 & 0.247 & 0.29 \\
\hline & Right building & 5.54 & 5.21 & 0.631 & 0.967 \\
\hline \multirow[t]{2}{*}{ Northridge } & Left building & 4.80 & 4.23 & 0.413 & 0.525 \\
\hline & Right building & 2.65 & 1.92 & 1.27 & 0.917 \\
\hline
\end{tabular}

under the Loma Prieta earthquake. On the other hand, for the fully infilled frames, the buildings behave elastically with no plastic strain observed, except for the right building with rigid base under the Northridge earthquake where the strain in the columns of the first floor exceeds the elastic limit by about $13.40 \%$.

The ratios of the ductility demand, interstory drift and peak story shear of the buildings under different earthquakes (independent vibrations case) are presented in Table 6. The table shows that, for almost all cases, the ductility demand for all stories did not exceed the available one except for two cases with a maximum value of only $4 \%$. These two cases occurred at the left building under the effect of the Loma Prieta earthquake. This is attributed to the location of the fundamental period of this building at a high acceleration level on the response spectrum of the Loma Prieta earthquake. It is also observed that, for the all examined cases, the interstory drift did not exceed the standard allowable limits which is 0.025 times the story height for structures with natural period less than $0.70 \mathrm{~s}$ and 0.02 


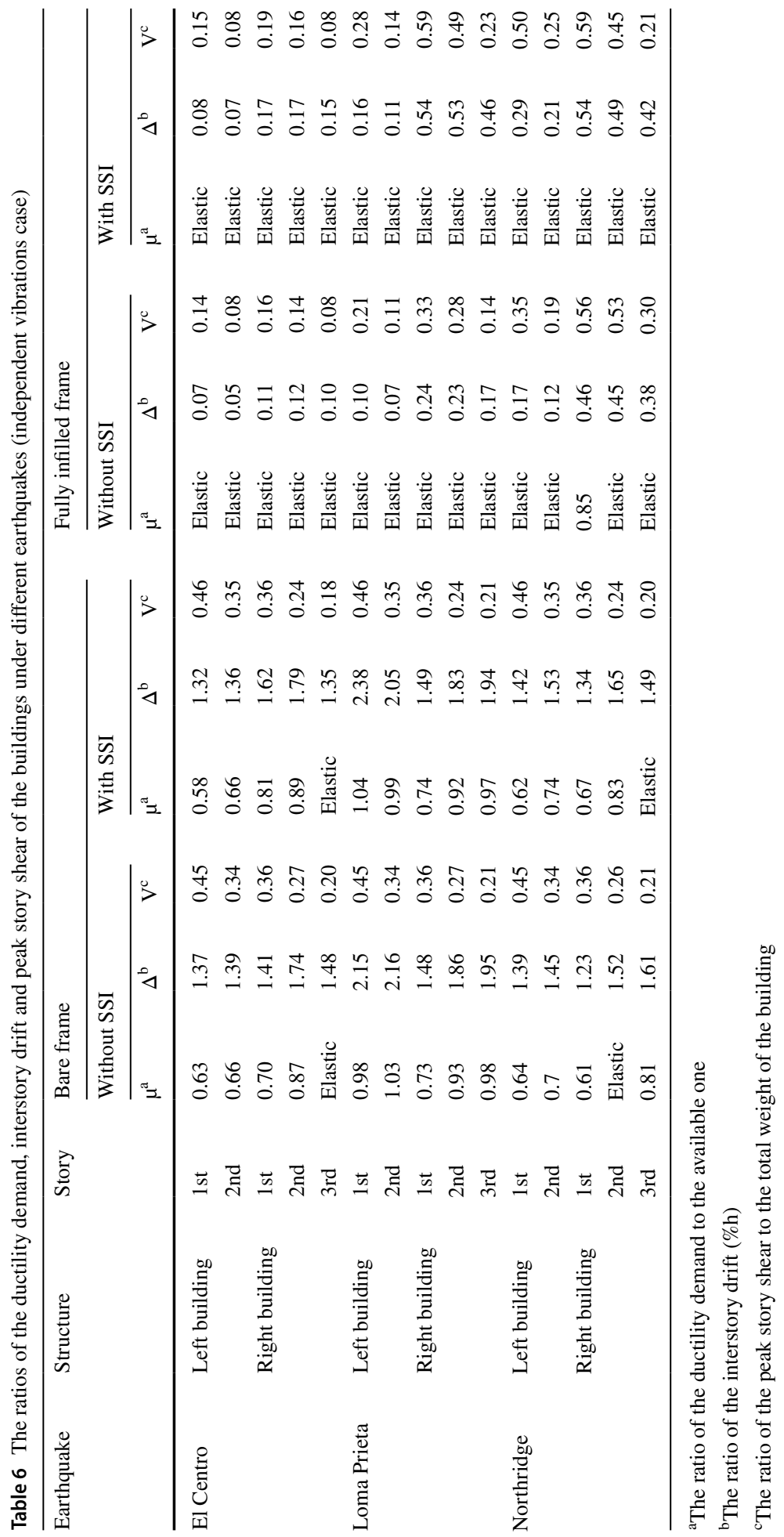




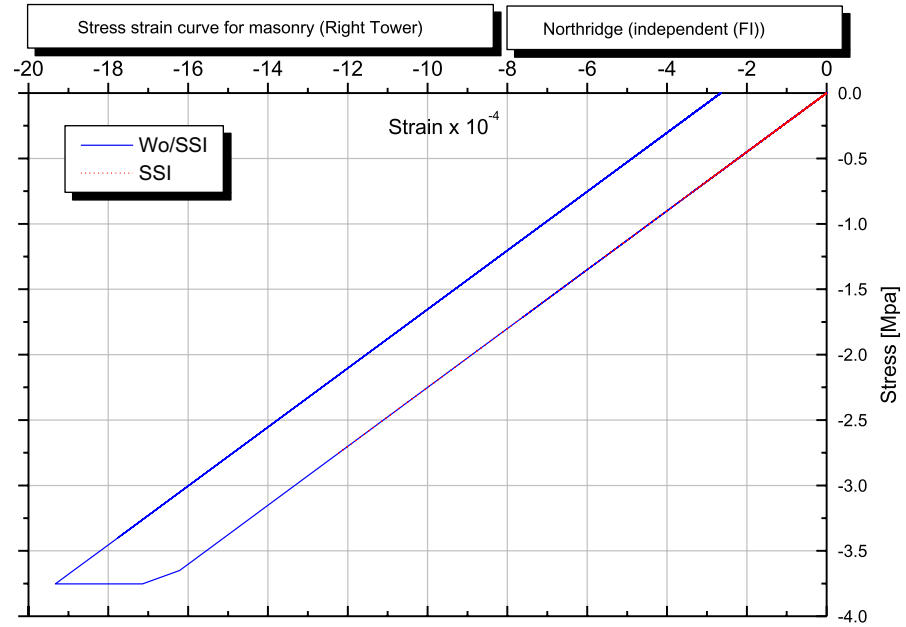

Fig. 9 Stress-strain curve for the first floor masonry of the right building

times the story height for structures with natural period of $0.70 \mathrm{~s}$ or greater as per UBC (1997). Regarding the story shear, Table 6 shows that, for bare frame buildings, the story shear reached the yield strength for almost all cases, except for the four elastic cases shown in the table. On the other hand, the infilled frame buildings behaved elastically, except for the first story of the right building with rigid base under the Northridge earthquake where $\mu$ reached 0.85 .

Figure 9 shows the stress-strain relationship of the strut of the first floor of the right building under the Northridge earthquake for the rigid base case. The results indicate that the strain in the infill exceeds the elastic strain limit by about $15.57 \%$. On the other hand, when the SSI is considered, the strain in the infill is decreased by about $36.40 \%$, as compared to the rigid base. For this case, the strain is maintained in the infill within the elastic range. Also, for all other cases, no plastic strain was observed in the infill.

\subsection{Comparison between pounding-involved versus independent vibrations of bare frame buildings without SSI}

This comparison between pounding-involved (PO) versus independent vibrations (ID) of bare frame buildings without SSI was conducted in order to clarify the influence of collisions between adjacent buildings on the response of each structure. Substantial increase in the displacement response of the right building (the more flexible one) in the outward direction, associated with minor to moderate decrease in the displacement in the inward direction, is observed due to pounding (see Fig. 10). The maximum absolute increase in the displacement reaches $47.86 \%, 78.17 \%$ and $18.31 \%$ under the El Centro, Loma Prieta and Northridge earthquakes, respectively. On the other hand, collisions caused moderate reduction in the displacement response of the more rigid left building in the inward direction, whereas no significant change in the outward direction was observed.

Figure 11 shows the peak acceleration values for both buildings. It is observed that pounding results in the increase in the acceleration values for both buildings. For the left building, the peak acceleration increased 11.27 and 10.62 times for the El Centro and Loma Prieta earthquakes, respectively. Moreover, the peak acceleration for the right 


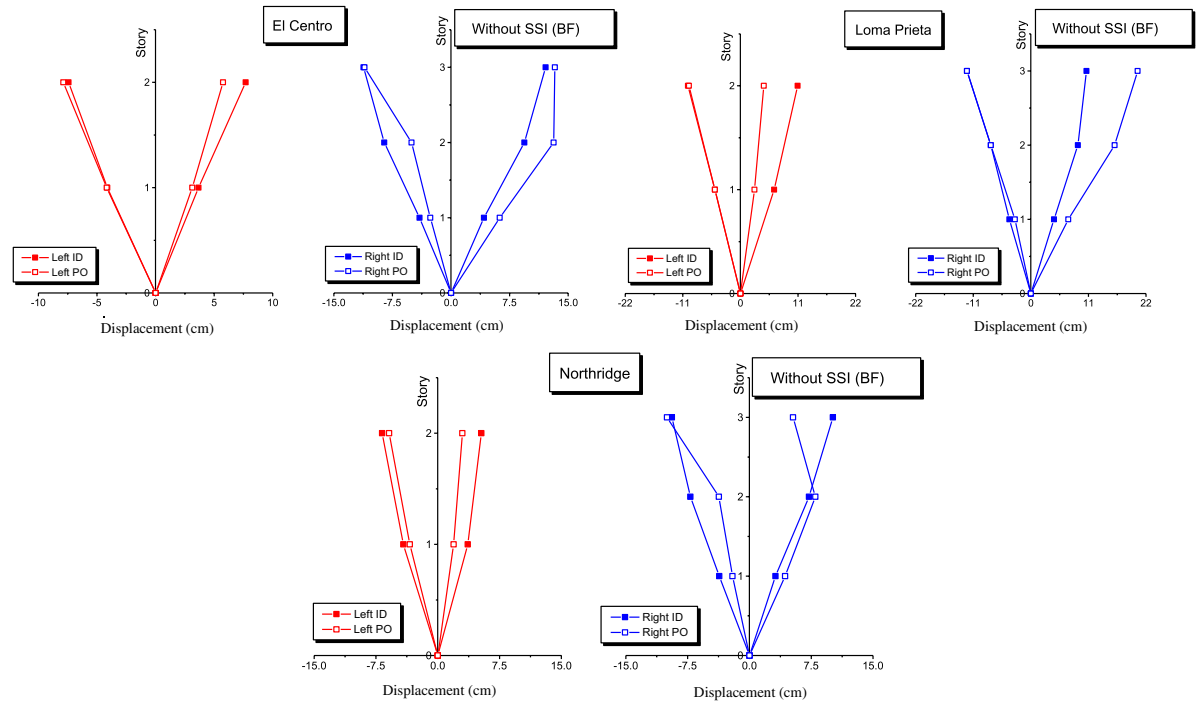

Fig. 10 Peak displacements for the pounding-involved and independent vibrations of bare frame buildings without SSI
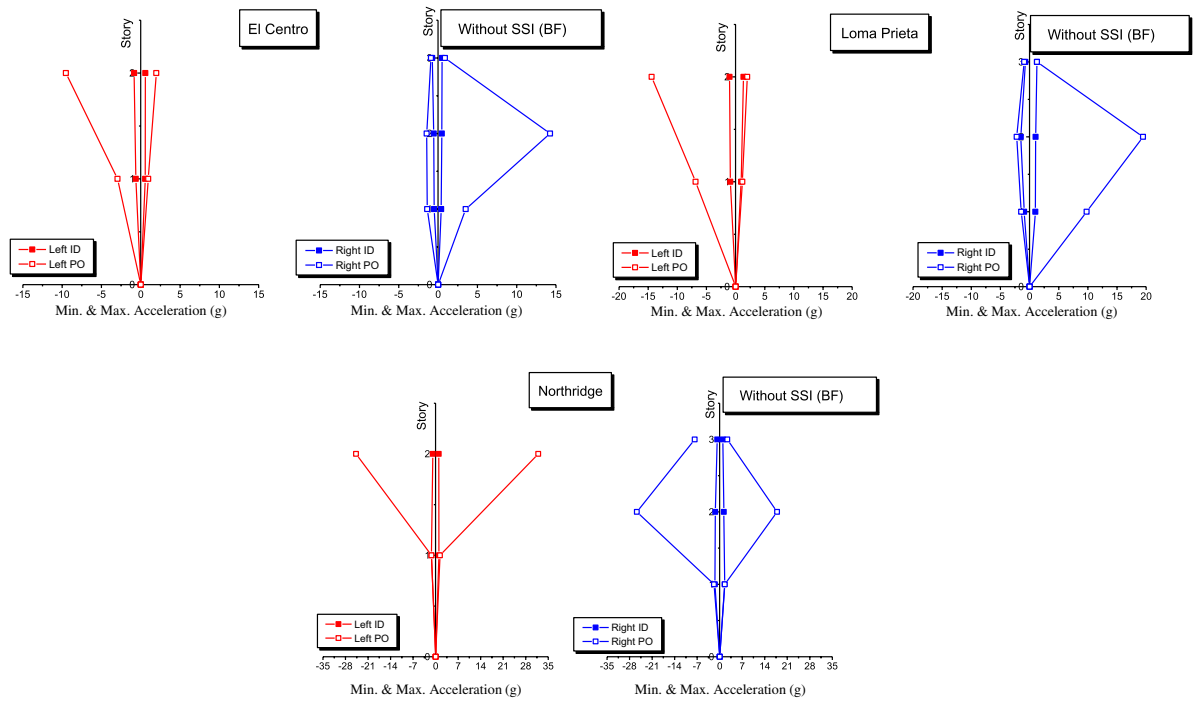

Fig. 11 Peak accelerations for the pounding-involved and independent vibrations of bare frame buildings without SSI

building increased 25.8 and 12.93 times for the El Centro and Loma Prieta earthquakes, respectively. Under the effect of the Northridge earthquake, collisions highly increased the peak acceleration values for the left and right buildings (32 times and 19 times, respectively). This behavior may be due to the large value of collision force that occurred during the Northridge earthquake (it reached 59.4 tons at the 2nd story). This significant collision 
force resulted in a strain in the upper part of the steel column of the 2 nd floor of the left building (the point is located directly under the impacted surface) that exceeded the ultimate strain. This resulted in a local failure of the steel column; consequently the run was terminated at this stage.

It can be stated that pounding increases the displacement of the more flexible building in the outward direction and decreases the displacement of the more rigid structure in the inward direction. Pounding also causes significant increase in the acceleration at the locations of collisions.

\subsection{Comparison between pounding-involved versus independent vibrations of bare frame buildings with SSI}

In the next stage of the study, the flexibility of the soil was considered for the bare frame buildings. Comparison between the pounding-involved and independent vibrations clearly indicates that pounding significantly affects the responses of both buildings. It resulted in the increase in the peak acceleration of the left building (more rigid one) 13, 13 and 11 times, as compared to the no pounding case for the El Centro, Northridge and Loma Prieta earthquakes, respectively. On the other hand, the right building (more flexible one) was influenced by pounding even more significantly. Its peak acceleration increased 27, 14 and 12 times, as compared to the no pounding case for the El Centro, Loma Prieta and Northridge earthquakes, respectively (see Fig. 12).

Figure 13 shows the displacement time history of different floors for both structures under the Loma Prieta earthquake. It can be seen from the figure that the left building behaved plastically during independent vibrations and a permanent displacement towards the inward direction occurred. Collisions affected the displacement response of both buildings. They caused both buildings to behave plastically with permanent displacement
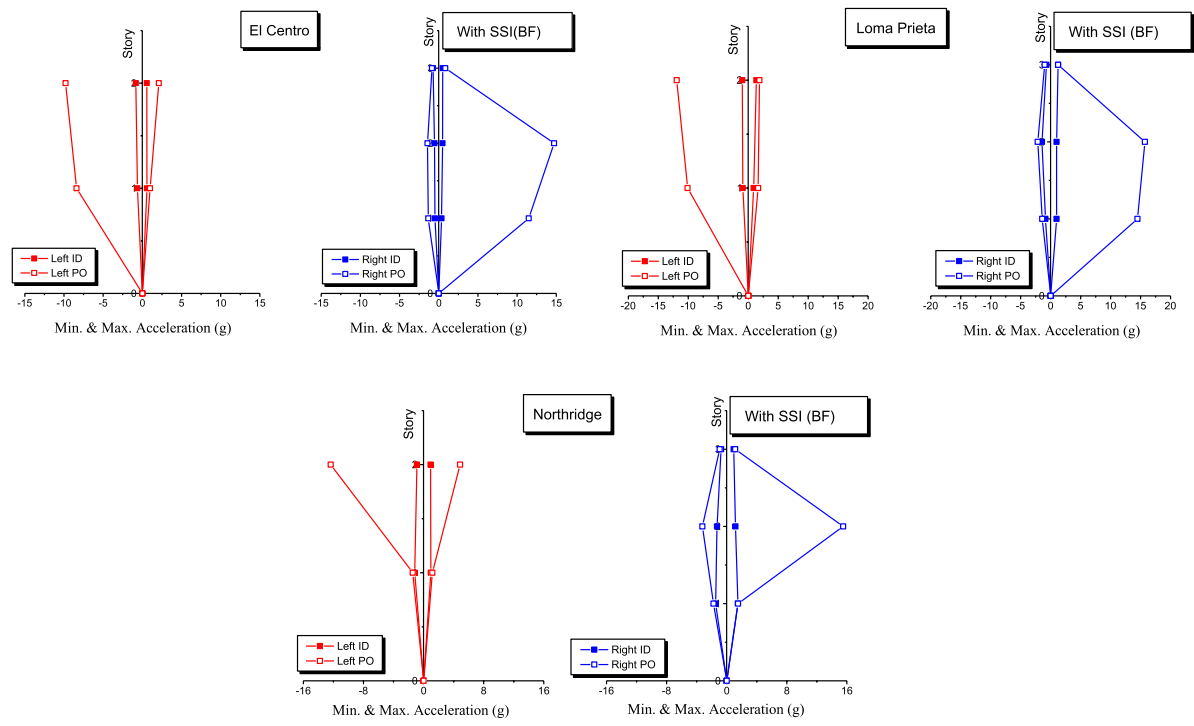

Fig. 12 Peak accelerations for the pounding-involved and independent vibrations of bare frame buildings with SSI 

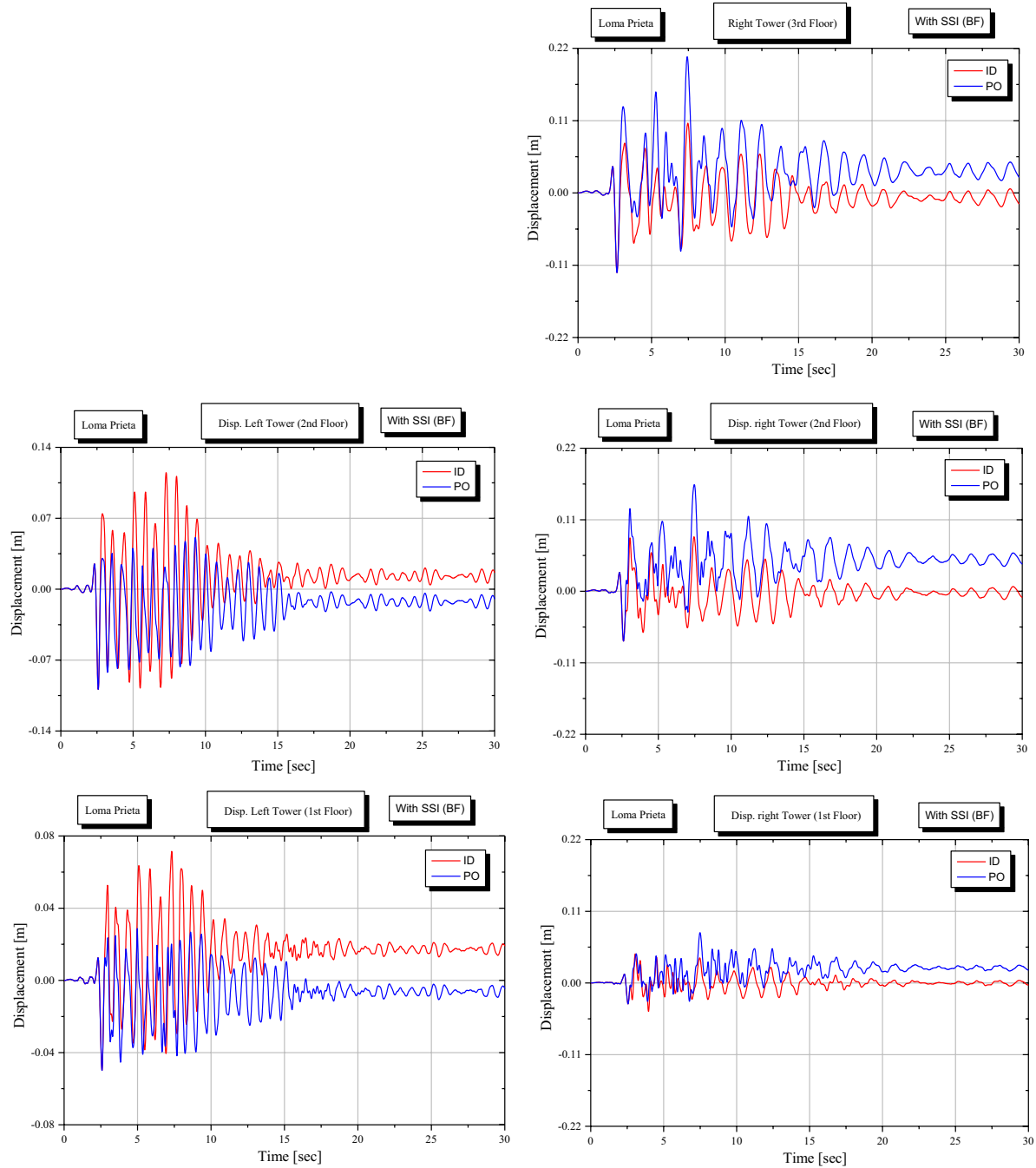

Fig. 13 Displacement time histories for pounding-involved and independent vibrations of bare frame buildings with SSI under the Loma Prieta earthquake

towards the outward directions. Generally speaking, the induced pounding resulted in the decrease in the peak displacement of the 1 st and 2 nd floor of the left building by $30.3 \%$ and $14 \%$, respectively. On the other hand, it increased the peak displacement of the 1 st, 2 nd and 3rd stories of the right building by $73 \%, 95.5 \%$ and $70.50 \%$, respectively. Impact forces between the two adjacent stories of the left and right buildings under the effect of different earthquakes were observed. Generally, the impact forces are larger at the 2nd story level and a large number of impacts occur. For the Northridge earthquake, however, impacts are observed only at the 2nd story level (see Fig. 14).

Figure 15 shows the strain time history of the steel columns of the left and right building for the independent and pounding-involved vibrations. It can be seen from 


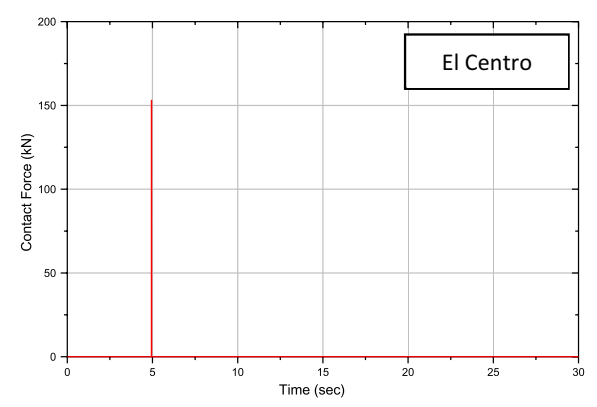

a. 1st Floor

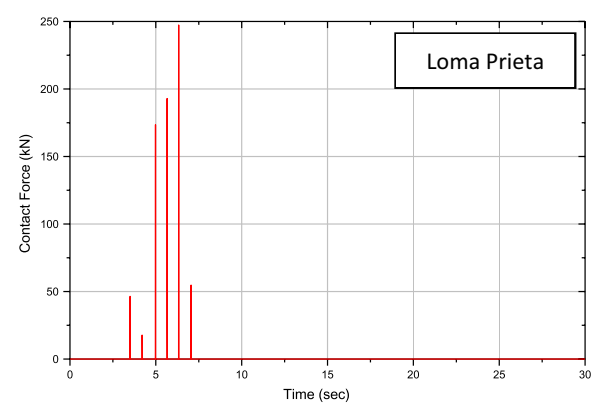

a. 1st Floor

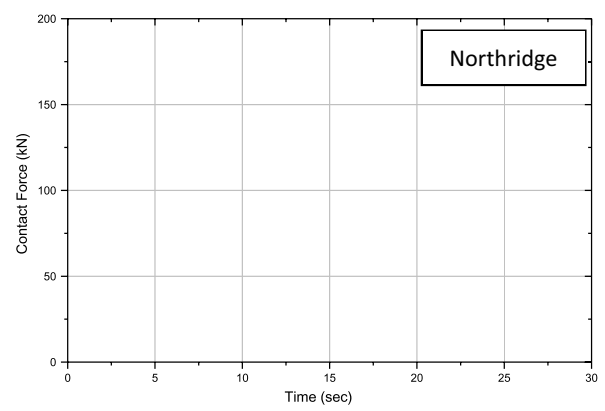

a. 1st Floor

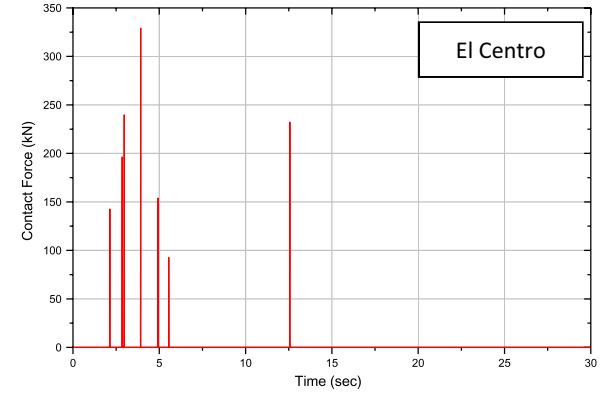

b. 2nd Floor

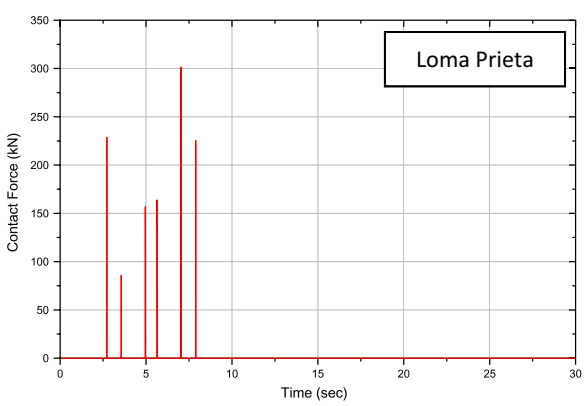

b. 2nd Floor

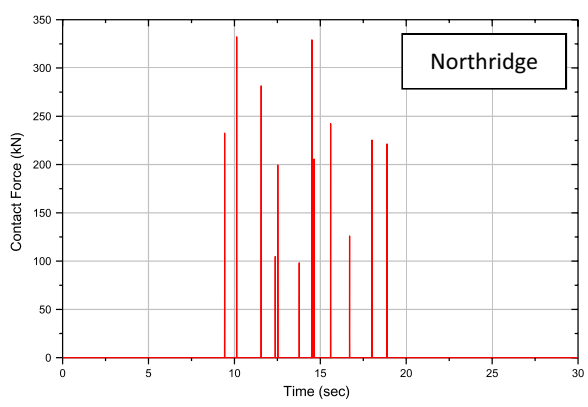

b. 2nd Floor

Fig. 14 Pounding force at the first and second story for bare frame buildings with SSI

the figure that pounding between the adjacent buildings resulted in the increase in the maximum strain in the steel columns of the left and right building under the El Centro earthquake 1.25 and 2.5 times, respectively, as compared to the no pounding case. Moreover, it increased the maximum strain in the steel columns of the right building 2.8 and 3.5 times for the Loma Prieta and Northridge earthquakes, respectively. It also decreased the maximum strain in the steel columns of the left building under the Loma Prieta and Northridge earthquakes by $41 \%$ and $23.8 \%$, respectively. 

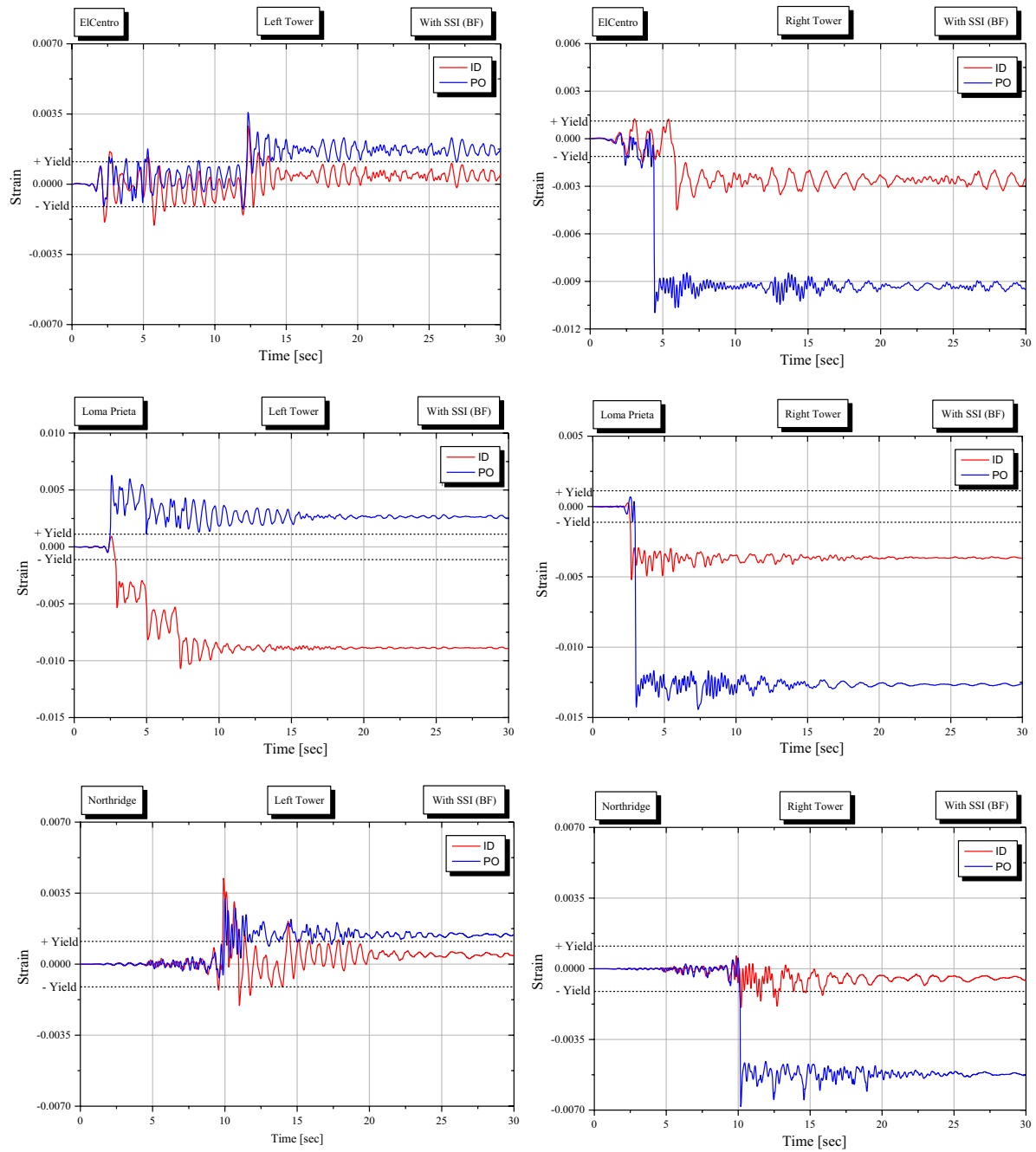

Fig. 15 Strain time history of the steel columns of the left and right building

\subsection{Comparison between pounding-involved versus independent vibrations of infilled frame buildings with and without SSI}

For the pounding-involved case, when the flexibility of the soil is neglected, it is found that the adjacent buildings vibrate independently under the effect of the three ground motions and no pounding was observed. The peak displacement of the 1 st story reached $3.41,7.17$ and $14 \mathrm{~mm}$ and the corresponding values for the 2nd story are 6.95, 14.3 and $28.0 \mathrm{~mm}$ for the El Centro, Loma Prieta and Northridge ground motions, respectively. It is also worth mentioning that these values are smaller than $30 \mathrm{~mm}$ which is the seismic gap between the adjacent buildings. On the other hand, considering the flexibility of the soil increased the displacements of the independent vibrations for both buildings. As a 


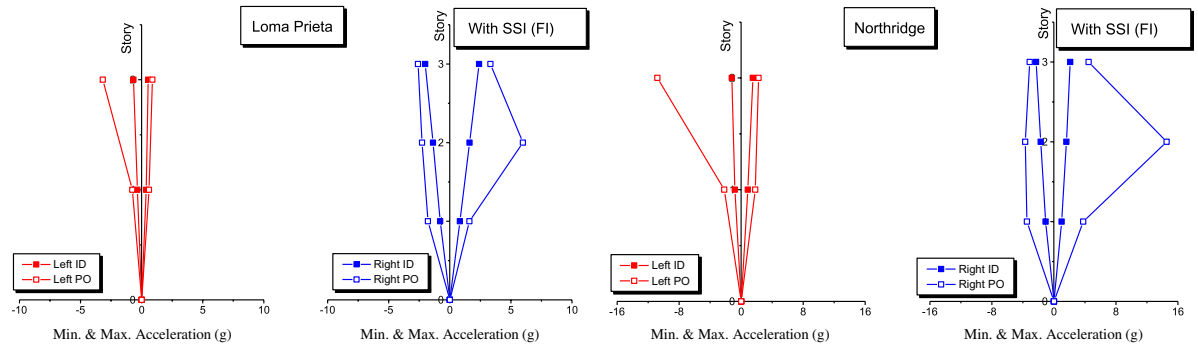

Fig. 16 Peak accelerations for the pounding-involved and independent vibrations for infilled frame buildings with SSI
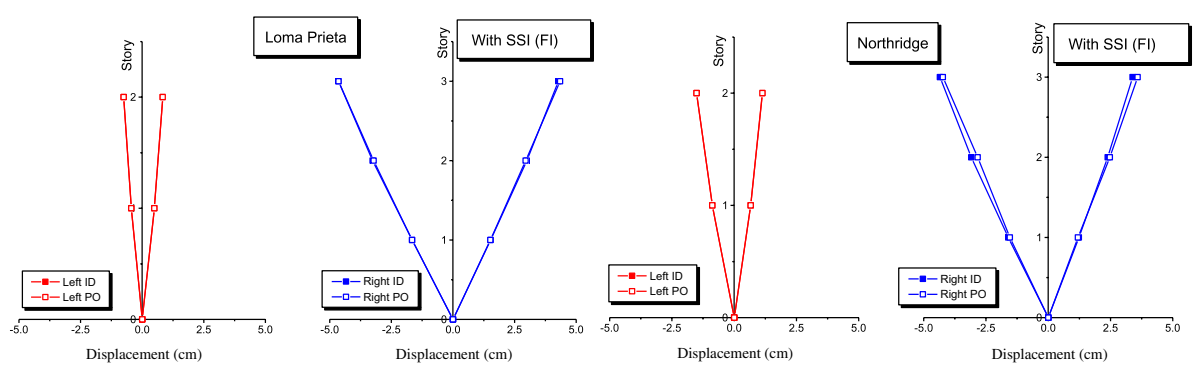

Fig. 17 Peak displacements for the pounding-involved and independent vibrations for infilled frame buildings with SSI

result of this increase, pounding between the 2nd stories of the adjacent structures under the effect of the Loma Prieta and Northridge ground motions was observed. It caused significant increase in the accelerations at the locations of collisions. For example, it increased the peak acceleration of the left building 2.0 and 4.80 times for the 1 st and 2nd story, respectively, under the effect of the Loma Prieta earthquake. Moreover, it increased the peak acceleration for the 1st and 2nd story of the left building 2.5 and 7 times, respectively, under the effect of the Northridge earthquake (see Fig. 16). Collisions also increased the peak acceleration of the 1 st and 2 nd floor of the right building 2.15 and 3.70 times, respectively, under the Loma Prieta earthquake. It also increased the peak acceleration of the 1 st and 2 nd floor of the right building under the Northridge earthquake 3.56 and 8.54 times, respectively, as compared to the no pounding case. It should also be mentioned that no pounding was observed for the buildings under the effect of the El Centro earthquake, where the peak displacement of the left building reached 2.57 and $4.57 \mathrm{~mm}$ for the 1st and 2nd story, respectively, while it reached 5.18 and $10.2 \mathrm{~mm}$ for the $1 \mathrm{st}$ and $2 \mathrm{nd}$ floor of the right building, respectively. These values are also smaller than the $30 \mathrm{~mm}$ gap distance.

Although collisions substantially amplified the accelerations, as mentioned above, the displacement response of the left building is nearly unaffected by pounding, while the right building was only slightly affected (see Fig. 17). It is also worth mentioning that both buildings behaved elastically and no plastic strains were observed neither in the steel columns nor in the masonry infill. 


\subsection{Comparison between pounding-involved responses of bare frames with and without SSI (Case 1)}

Figure 18 shows that, under the effect of the El Centro earthquake, the incorporation of SSI in the analysis increased the peak absolute acceleration of the 1st floor of the left and right building by 2.84 and 3.26 times, respectively, as compared to the fixed base case. On the other hand, no significant adverse effect was observed for other floors. Moreover, the results reveal that pounding occurred between the adjacent stories of both structures. It was observed that considering SSI results in an increase in the pounding forces for both stories with different values, i.e. a peak pounding force of only 6.5 ton was observed at the 1st floor for the rigid base case, while the value of 15.30 ton was recorded for the case of flexible soil. On the other hand, only a minor increase of $4.44 \%$ was observed for the peak pounding force at the 2 nd story. For the Loma Prieta earthquake, pounding was observed for both cases for the 1st and 2nd floors. Considering the SSI leads to an increase in the peak pounding force for the 1 st story by $77 \%$, whereas it results in a slight decrease (by about $7 \%$ ) in the pounding force for the 2 nd story. Moreover, it increased the peak acceleration for the 1 st story for two buildings by about $47 \%$. On the other hand, it decreased the peak acceleration of the 2nd story for the left and right building by $17 \%$ and $19 \%$, respectively. Under the Northridge earthquake, both rigid and flexible base frames experienced pounding between the 2 nd stories and no pounding occurred between the 1 st stories. The incorporation of SSI decreased the peak pounding force by about $44 \%$. Moreover, it decreased the peak acceleration of the 2 nd story of the left building by about $61 \%$; and decreased the peak acceleration of the 2nd and 3rd story of the right structure by $40 \%$ and $85 \%$, respectively. On the other hand, no significant reduction was observed for the 1 st stories of both buildings (see Fig. 18). Figure 18c shows also a significant difference in the acceleration levels between the rigid base and the flexible base case, especially at the 2nd floors of the left and right buildings where collisions occur. After a deep insight into the

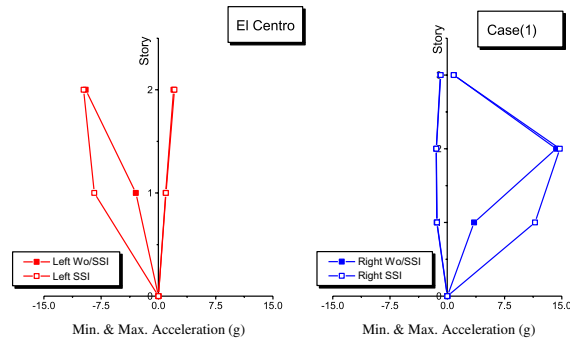

(a)

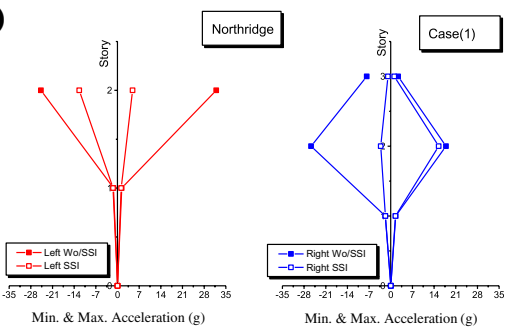

(c)

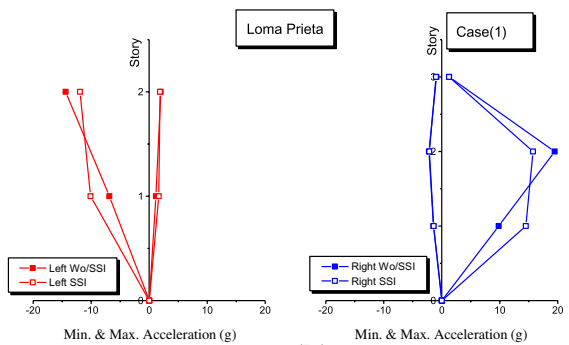

(b)

Fig. 18 Peak accelerations for the pounding-involved Case (1) 
Table 7 Maximum strains of the steel columns of the buildings under different earthquakes for pounding-involved responses (Case 1)

\begin{tabular}{llll}
\hline Earthquake & Structure & \multicolumn{2}{l}{ Maximum strain $\left(\times 10^{-3}\right)$} \\
\cline { 3 - 4 } & & Bare frame & \\
\cline { 3 - 4 } & & Without SSI & With SSI \\
\hline \multirow{2}{*}{ El Centro } & Left building & 4.50 & 3.58 \\
& Right building & 11.80 & 11.0 \\
Loma Prieta & Left building & 7.02 & 6.29 \\
& Right building & 14.20 & 14.40 \\
Northridge & Left building & Failure & 3.23 \\
& Right building & 11.40 & 6.81 \\
\hline
\end{tabular}

behavior of both cases it was found that this effect is caused by very high pounding forces that occurred in the rigid base case (1.8 times larger than that for the flexible base case). These collisions resulted in large strains in the left building with fixed base which exceeded the ultimate strain. This extremely high strain caused local failure in the 2nd floor columns of the left building with rigid base and resulted in peak acceleration as high as 2.6 times larger than that of the SSI case.

Table 7 shows the maximum strains of the steel columns for the two buildings for the rigid foundation and SSI responses. It is observed that, for all earthquake excitations, the two buildings behaved plastically. As a general trend, considering the SSI reduced the inelastic response of the two structures under all considered excitations. For instance, under the El Centro earthquake, the inelastic response of the left and right building decreased by about $20 \%$ and $7 \%$, respectively. Moreover, for the Loma Prieta earthquake, the inelastic response of the left building decreased by about $10 \%$. On the other hand, no significant effect was observed for the right building. A significant reduction in the plastic strain of the left and right buildings was observed under the Northridge earthquake. It is obvious that the contribution of SSI has a considerable effect on the decrease in the ductility demand of the steel buildings.

\subsection{Comparison between pounding-involved responses of fully infilled frames with and without SSI (Case 2)}

In the next stage of the investigation, the influence of contribution of the flexible base on the response of fully infilled frames was studied and compared with the results of rigid base. It is noticed that, for the case with rigid base, no collisions between the buildings was observed when buildings behaved independently during different earthquakes. This is attributed to the limited displacement values due to existence of infill. On the other hand, for the case of flexible base, pounding was observed at the 2nd story under the Loma Prieta and Northridge earthquakes only. This resulted in an increase of the acceleration in all floors (reaching the peak at the 2nd floor of the left building) by about $787 \%$ and $778.6 \%$ for the Loma Prieta and Northridge earthquake, respectively, as compared to the rigid base case (see Fig. 19). For the rigid base case under the Loma Prieta earthquake, no pounding was observed between the adjacent buildings. The incorporation of SSI increased the displacements of buildings. Accordingly, pounding between the 2 nd floors of the buildings was observed (see Fig. 20b). For the flexible base case, the peak displacement of the 1st and 2 nd floor for the left building increased by $62.69 \%$ and $63.16 \%$, respectively, and the 

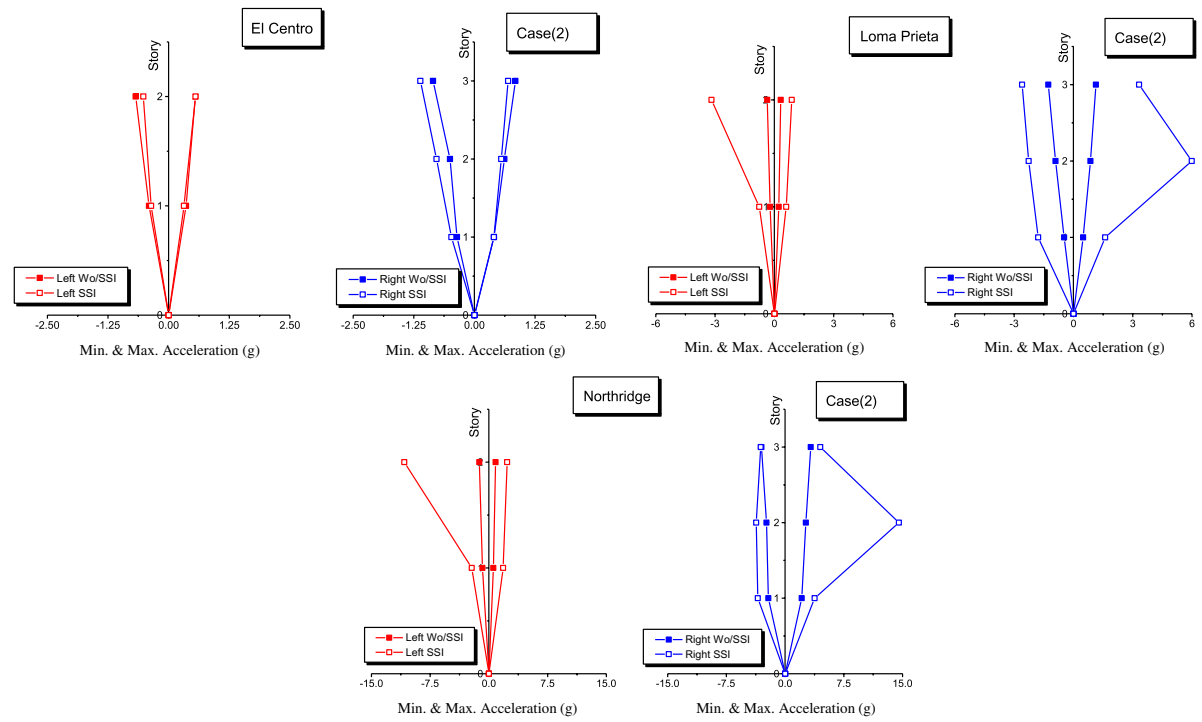

Fig. 19 Peak accelerations for the pounding-involved Case (2)

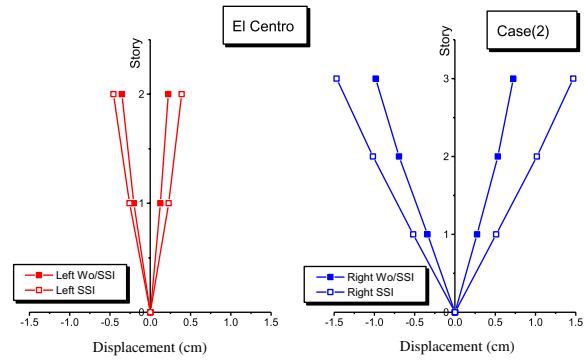

(a)

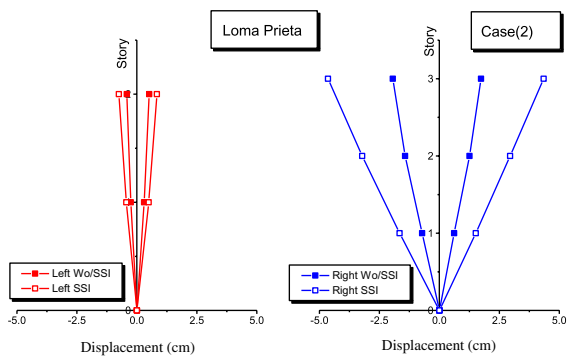

(b)

Fig. 20 Peak displacements for the pounding-involved Case (2)

peak displacement of the 1st, 2nd and 3rd floor of the right building increased by $131.52 \%$, $124.96 \%$ and $139.18 \%$, respectively. Under the El Centro earthquake, for which pounding was not observed, minor decrease in the peak acceleration response occurred at the 1 st and 2nd floor of the left building (by $10 \%$ and $18 \%$, respectively). For the right building, however, SSI increased the peak acceleration of the floors (1st, 2nd and 3rd) by about $17.6 \%$, $26.7 \%$ and $30.4 \%$, respectively (see Fig. 19). It can be concluded that generally, the inclusion of SSI in the analysis increased the peak displacement of buildings and consequently increased the peak acceleration significantly if pounding occurs.

Figure 20a shows the peak displacements for the pounding-involved response for the El Centro earthquake. It can be noticed that the contribution of the soil flexibility in the analysis increased the peak displacement of all floors for the two buildings. This notice seems logical, because the insertion of the soil flexibility increased the natural period of the buildings (see Table 1) and, consequently, increased the overall flexibility of buildings. The peak displacement of the 1st and 2nd floor for the left building increased by $25.40 \%$ 
and $29.46 \%$, respectively, while the peak displacement of the 1st, 2nd and 3rd floor of the right building increased by $51.90 \%, 46.47 \%$ and $49.39 \%$, respectively. Moreover, due to the overall limited displacements, no plastic response was observed for both buildings. It can be noticed that no pounding was observed between the buildings for both cases (with and without SSI).

For the rigid base case under the Northridge earthquake, no pounding between the adjacent buildings was observed. The incorporation of SSI increased the displacement of buildings which resulted in the occurrence of pounding between the 2nd floors (see Fig. 21). For the flexible base case, the displacement of the 1st and 2nd floor for the left building increased by $73.47 \%$ and $79.55 \%$, respectively, while minor increase in the displacement of the 1 st, 2nd and 3rd floor of the right building (by $10.24 \%, 0.93 \%$ and $7.91 \%$, respectively) was observed.
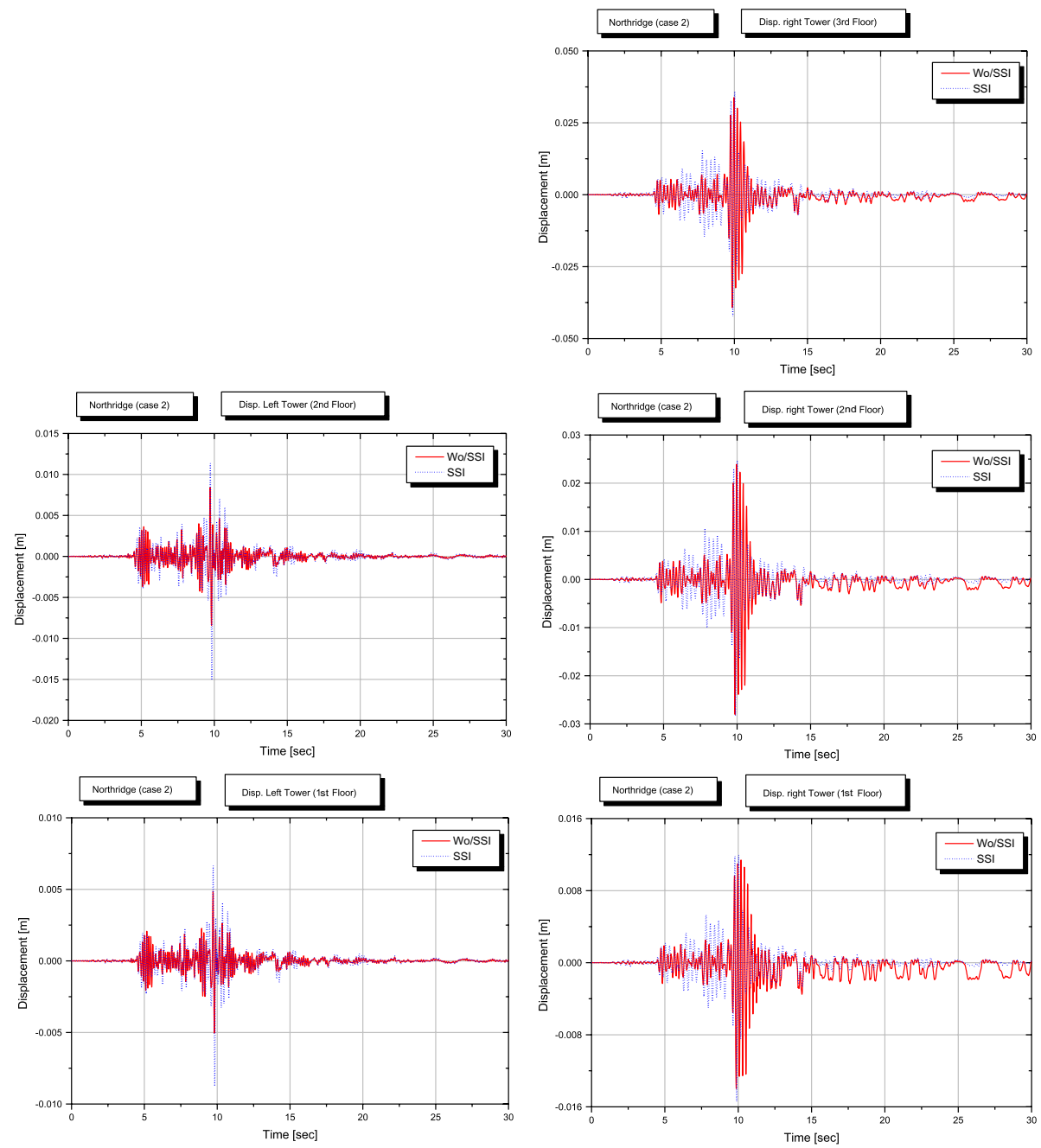

Fig. 21 Displacement time histories for pounding-involved Case (2) under the Northridge earthquake 


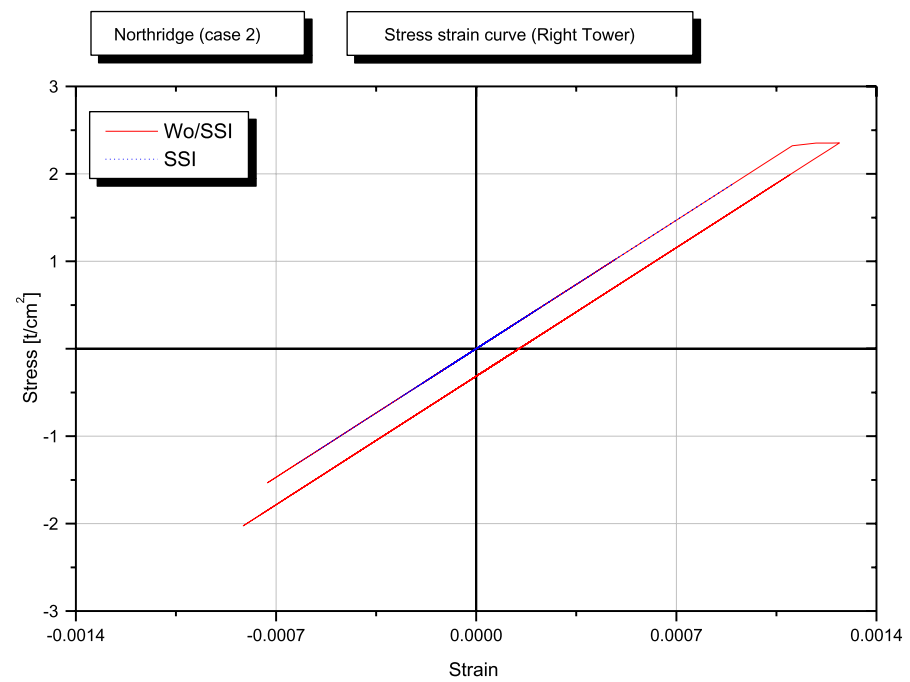

Fig. 22 Stress-strain relationship of the steel columns of the right building for Case (2) under the Northridge earthquake

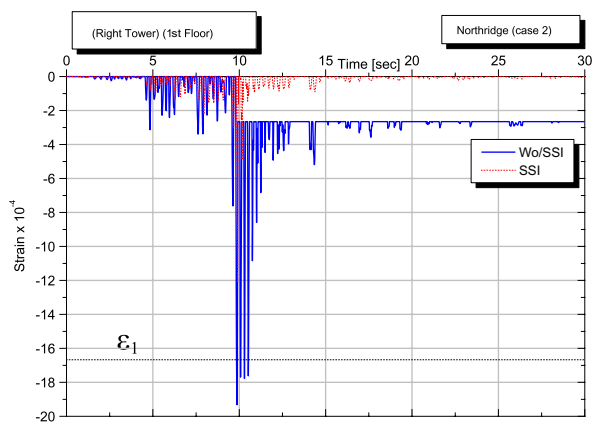

(a)

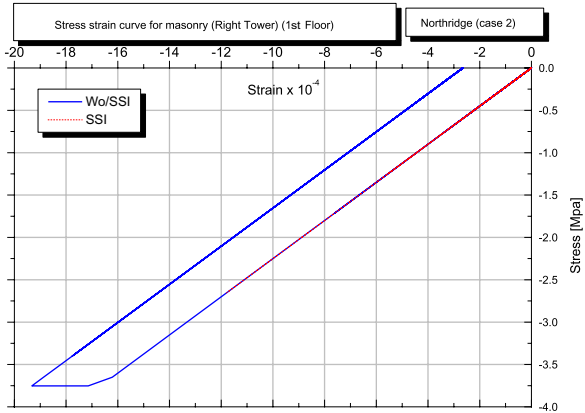

(b)

Fig. 23 Behavior of $1^{\text {st }}$ floor equivalent strut of the right building for Case (2) under the Northridge earthquake: a strain time history; b stress-strain relationship

Figure 22 shows the stress-strain relationship of the 1st floor columns of the right building under the effect of the Northridge earthquake. For the fixed base case, plastic behavior of the columns was observed and the strain in the columns exceeded the yielding point by $13.39 \%$. Moreover, at about the tenth second, the strain of the infill panel at the 1 st floor exceeded its elastic strain limit by about $15.56 \%$ (see Fig. 23). On the other hand, considering the soil flexibility kept both the columns and the infill of the right building in the elastic stage.

The general behavior of the infilled frames can be summarized as following. Taking SSI into consideration elongates the natural structural period and hence increases the displacements. If the increased displacements result in pounding, significant increase in the accelerations at the locations of collisions will take place. 


\subsection{Comparison between pounding-involved responses of frames with and without SSI (Case 3)}

This case considers that the left building is fully infilled while the right building has no infill walls (refer to Case (3) in Fig. 1). The results reveal that, considering the flexibility of the soil generally decreases the peak absolute acceleration of both floors of the left building under the effect of the three ground motions, except for the 2nd floor under the Loma Prieta earthquake where an increase of $25.15 \%$ was observed (see Fig. 24). This is because considering SSI decreased the pounding force by $15.80 \%$ and $8.10 \%$ for the El Centro and Northridge earthquakes, respectively. On the other hand, it increased the pounding force by $33.4 \%$ for the Loma Prieta earthquake where pounding between the two buildings was observed only at the 2nd floor level. Considering SSI also caused a minor to moderate change in the peak acceleration of the right building (see Fig. 24). The maximum percentage of reduction reached $15.79 \%$ and $14.93 \%$ at the 2 nd floor under the El Centro earthquake and at 3rd floor under the Northridge earthquake, respectively. On the other hand, the maximum increase reached $16.55 \%$ at the 2 nd floor under the effect of the Loma Prieta earthquake.

Figure 25 shows the peak displacements of the left and right buildings under the effect of different earthquakes. The incorporation of SSI in the analysis increased the displacement of each floor in a different way. While minor increase was observed for both buildings under the El Centro earthquake, moderate increase was observed for both the Loma Prieta and Northridge earthquakes. Considering the SSI increased the displacement of the 1st and 2nd floor of the left building by $28.68 \%$ and $20.95 \%$, respectively, under the Loma Prieta earthquake as well as by $73.46 \%$ and $79.55 \%$, respectively, under the Northridge earthquake. For the right building, the maximum increase in the displacement reached $23.19 \%$ at the 1 st floor for the Loma Prieta earthquake and $14 \%$ at the 2 nd floor for the Northridge
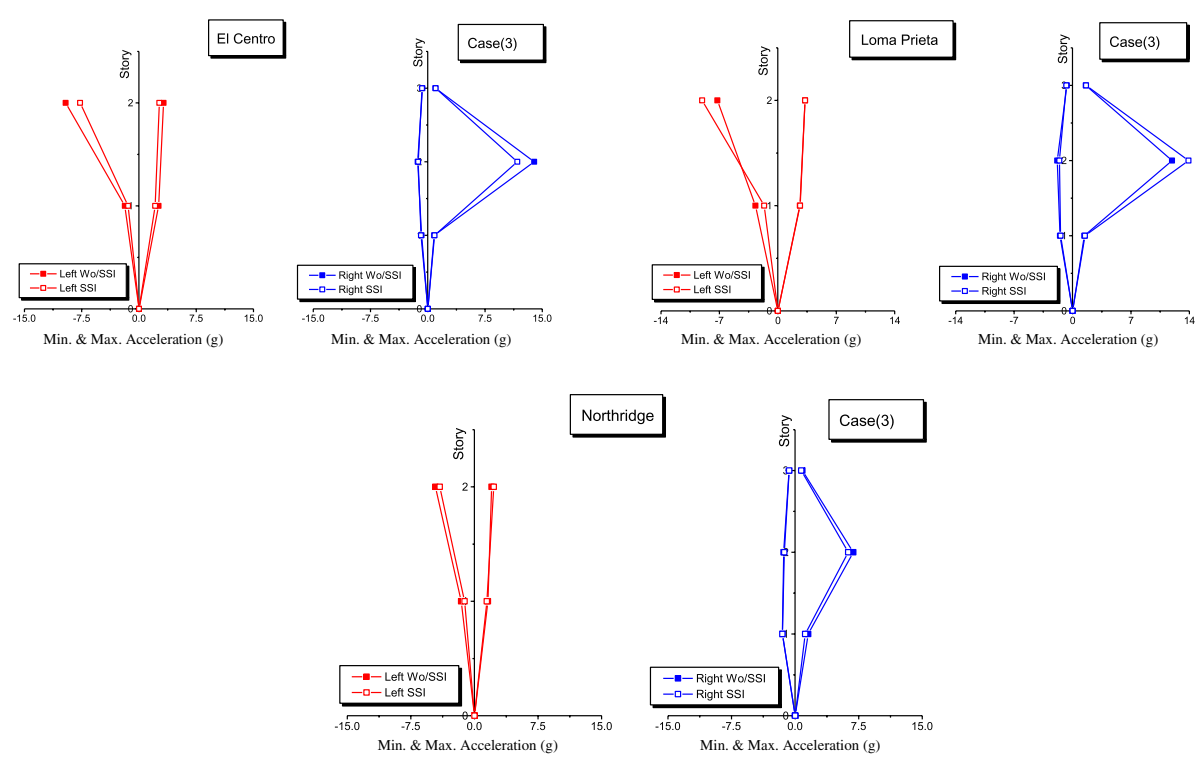

Fig. 24 Peak accelerations for the pounding-involved Case (3) 

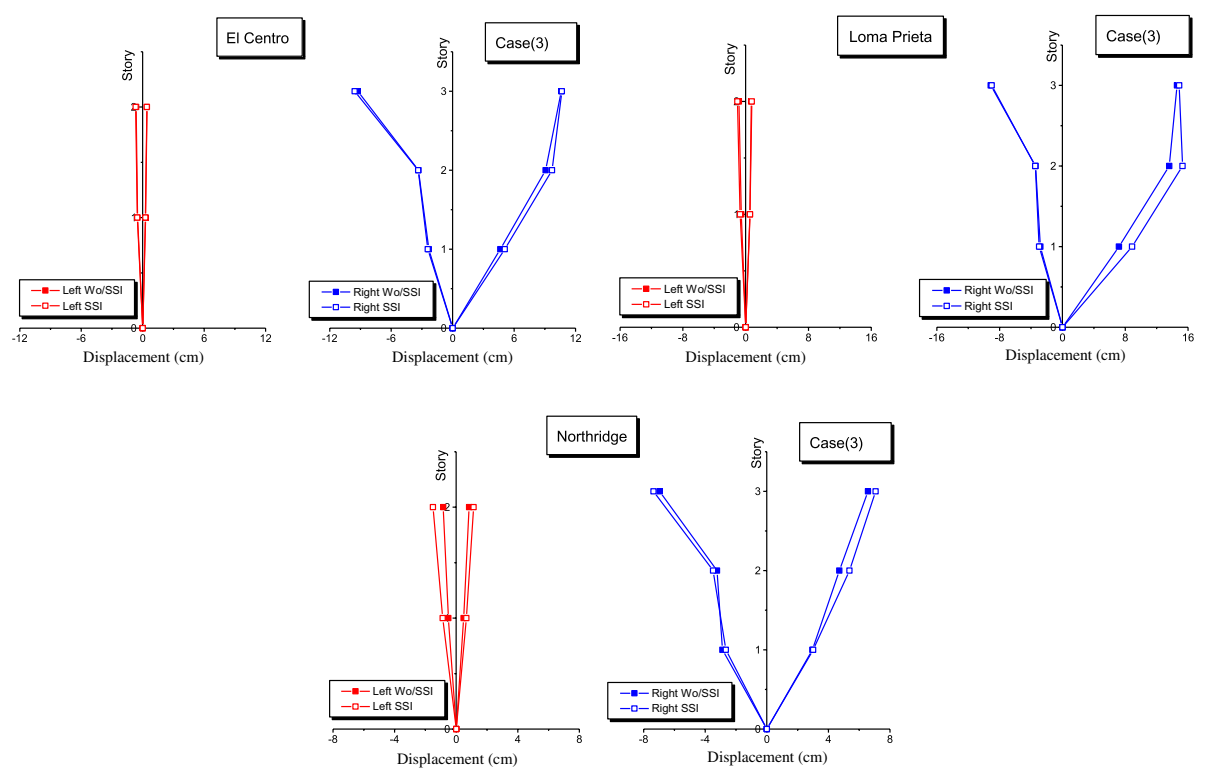

Fig. 25 Peak displacements for the pounding-involved Case (3)

earthquake. Generally speaking, taking SSI into consideration has minor to moderate effect on displacement or acceleration responses without specific trend.

The results show that the steel frame of the left building behaved elastically under the effect of the three ground motions for both cases (with and without SSI). The consideration of SSI decreased the strain of the steel frame of the left building by $28.13 \%$ and $4 \%$ under the El Centro and Loma Prieta earthquakes, respectively, while it increased the strain of the left building by $27.12 \%$ under the Northridge earthquake. No plastic strain was observed in the infill. The flexibility of the soil decreased the strain in the brick by $26.25 \%$ and $9.78 \%$ under the effect of the El Centro and Loma Prieta earthquakes, respectively. On the other hand, it increased the infill strain by $15.26 \%$ for the Northridge earthquake.

Figure 26 shows the strain time history of the steel columns of the right building under different earthquakes. The results show that plastic strain occurred in both cases (with and without SSI). For the right frame without SSI, the strain in the steel columns exceeded the elastic strain limit by 6.12, 11.87 and 1.46 times under the El Centro, Loma Prieta and Northridge earthquakes, respectively. Consideration of the flexibility of the soil decreased the strain by about $9 \%$ and $8.5 \%$ under the El Centro and Northridge earthquakes, respectively; and increased the strain by about $22.74 \%$ under the effect of the Loma Prieta earthquake.

\subsection{Comparison between pounding-involved responses of frames with and without SSI (Case 4)}

This case considers the right building fully infilled by masonry, while the left building has no infills (refer to Case (4) in Fig. 1). Moreover, this particular case was solved under two additional earthquake records, i.e. Kobe and San Fernando earthquakes, as listed in 

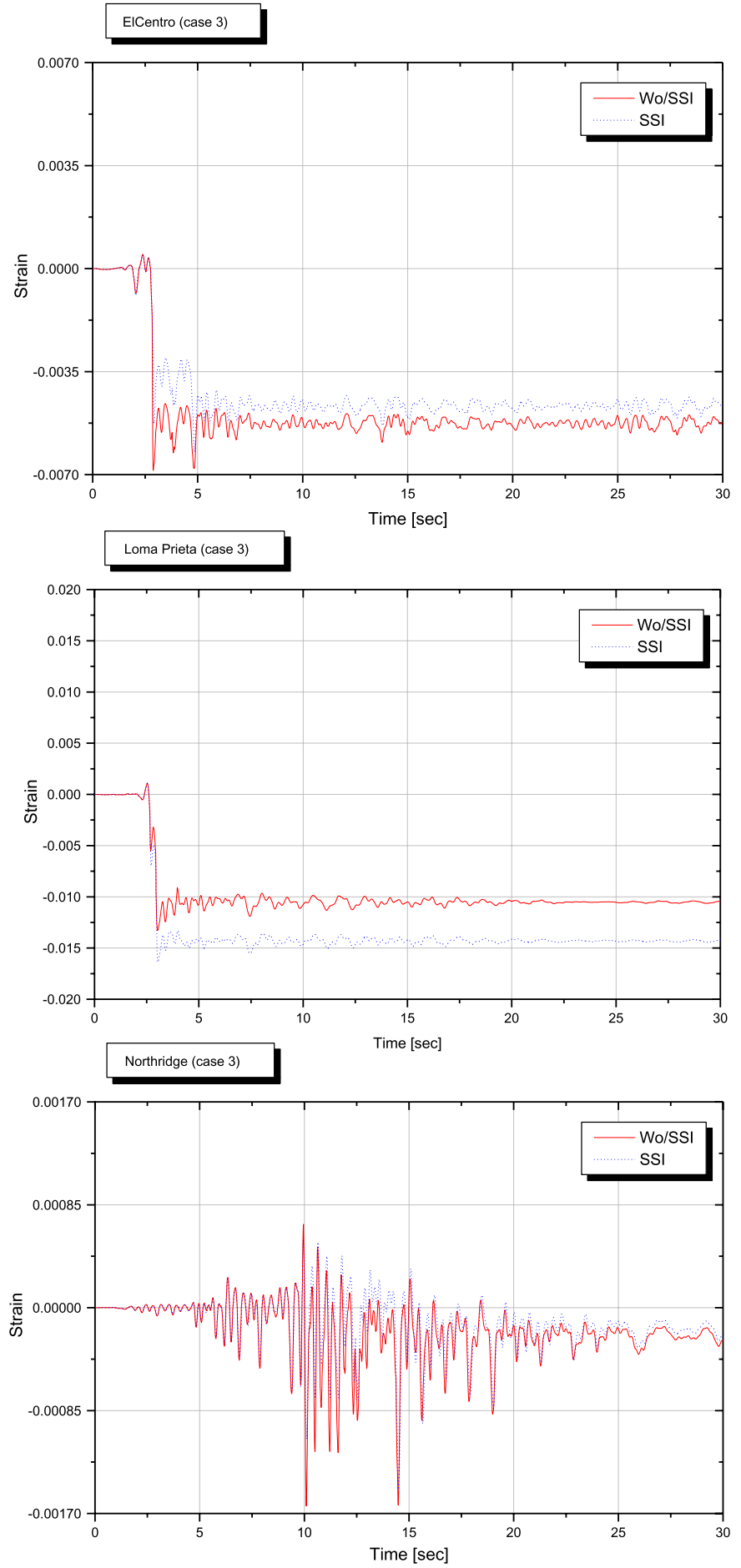

Fig. 26 Strain time history of the steel columns of the right building for Case (3) 
Table 2. The case was also solved considering different gap distances (i.e. 1, 3, and $5 \mathrm{~cm}$ ). The obtained results for all cases are summarized in Table 8. Moreover, Figs. 27, 28, 29, 30 and 31 show the obtained results for the case of $3 \mathrm{~cm}$ gap distance.

Figure 27 shows the resulting pounding forces. It can be seen from the figure that considering SSI increased the pounding force between the adjacent 2nd floors of buildings from $299 \mathrm{kN}$ (without SSI) to $336 \mathrm{kN}$ (with SSI) under the El Centro earthquake. No pounding occurred for the 1st floors of the rigid foundation case and a slight impact of only $6 \mathrm{kN}$ was observed for the SSI case. Under the effect of the Loma Prieta earthquake, considering SSI resulted in the increase in the pounding force for the 1st floors from $30 \mathrm{kN}$ (without SSI) to $68 \mathrm{kN}$ (with SSI) and in the increase in the pounding force of the 2nd stories from $559 \mathrm{kN}$ (without SSI) to $641 \mathrm{kN}$ (with SSI). Under the effect of the Northridge earthquake, the SSI also increased the impact force of the 1 st floors from $37 \mathrm{kN}$ (without SSI) to $60 \mathrm{kN}$ (with SSI) and decreased the impact force of the 2 nd floor from $225 \mathrm{kN}$ (without SSI) to $198 \mathrm{kN}$ (with SSI). For the Kobe earthquake, no pounding occurred at the 1st floor while the pounding force was equal to $179 \mathrm{kN}$ for rigid base and was reduced to $159 \mathrm{kN}$ for the SSI case. Finally, for the San Fernando earthquake, taking SSI into consideration increased the pounding force at the 1 st floor from $46 \mathrm{kN}$ to $71 \mathrm{kN}$ and also increased the pounding force at the 2 nd floor from $302 \mathrm{kN}$ to $368 \mathrm{kN}$.

Figure 28 shows that incorporation of SSI resulted in the increase in the peak accelerations of the three floors of the right building under the effect of the El Centro, Loma Prieta and San Fernando earthquakes. The maximum increase reached $21.59 \%$ at the 2 nd story and $53.63 \%$ at the 3rd story under the effect of the San Fernando earthquake. SSI also increased the acceleration of the 1st and 2nd floor of the left building by $46.58 \%$ and 25.24\% under the San Fernando earthquake. On the other hand, it decreased the acceleration of the 1st floor of the left building by $10.54 \%$ and $16.43 \%$ for both El Centro and Loma Prieta earthquakes, respectively. On the contrary to the El Centro and Loma Prieta earthquakes, considering the flexibility of the soil under the Northridge earthquake, resulted in the decrease in the peak acceleration of the 2nd and 3rd floor of the right building by $36 \%$ and $39.9 \%$, respectively. Moreover, it decreased the peak acceleration of the 2nd floor of the left building by $31.56 \%$, whereas it increased the peak acceleration of the 1 st floors of the left and right buildings by $118.79 \%$ and $8.86 \%$, respectively. For the Kobe earthquake, considering the flexibility of the soil decreased the peak acceleration of the 2nd floor of the left structure as well as the three floors of the right building with a maximum reduction of $36.55 \%$.

Figure 29 shows the peak displacements of the two buildings under different earthquakes. Considering the SSI generally increased the peak displacement of both buildings under almost all earthquakes. While there was a slight increase in displacement of the 1st and 2nd floors of the left building, there was a significant increase in displacements of the floors of the right building. The maximum increase in the peak displacement reached $168.58 \%, 148.53 \%$ and $138.40 \%$ for the $3 \mathrm{rd}, 1 \mathrm{st}$, and 2 nd floor, respectively under the Kobe earthquake.

Generally speaking, taking SSI into consideration has a minor to moderate effect on displacement or acceleration responses without specific trend. Moreover, it increases the chance of pounding occurrence for almost all cases.

The strain time history of selected steel columns for the case of $3 \mathrm{~cm}$ gap distance is shown in Fig. 30. For the left building, plastic strain was observed in both cases (with and without SSI). For the rigid base case, the strain in the steel columns exceeded the elastic strain limit for all cases with a maximum of more than 6 times the elastic strain limit under the effect of the Loma Prieta earthquake. On the other hand, consideration of the 


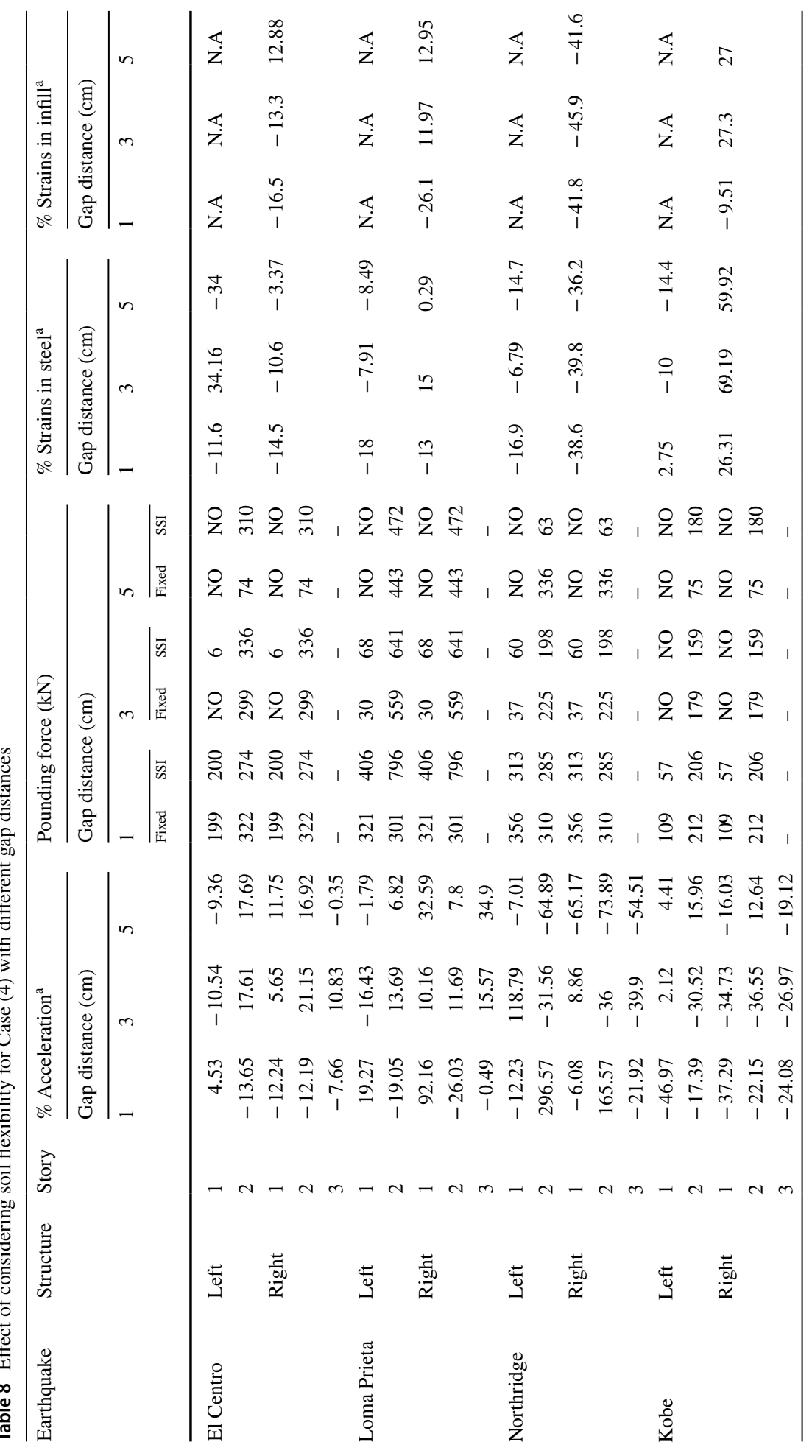




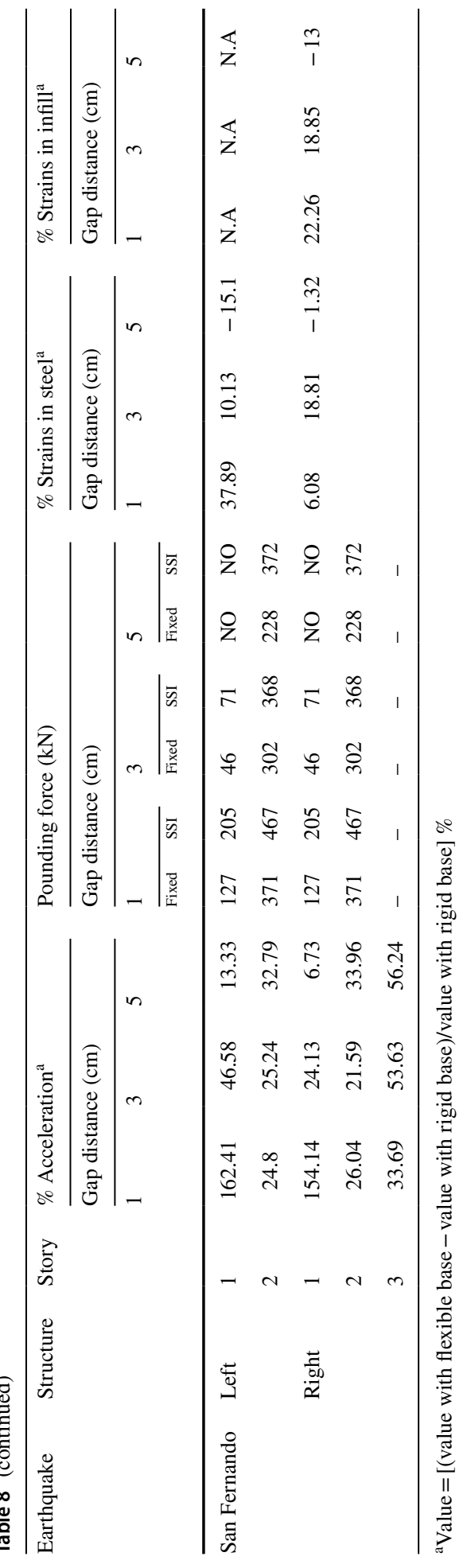



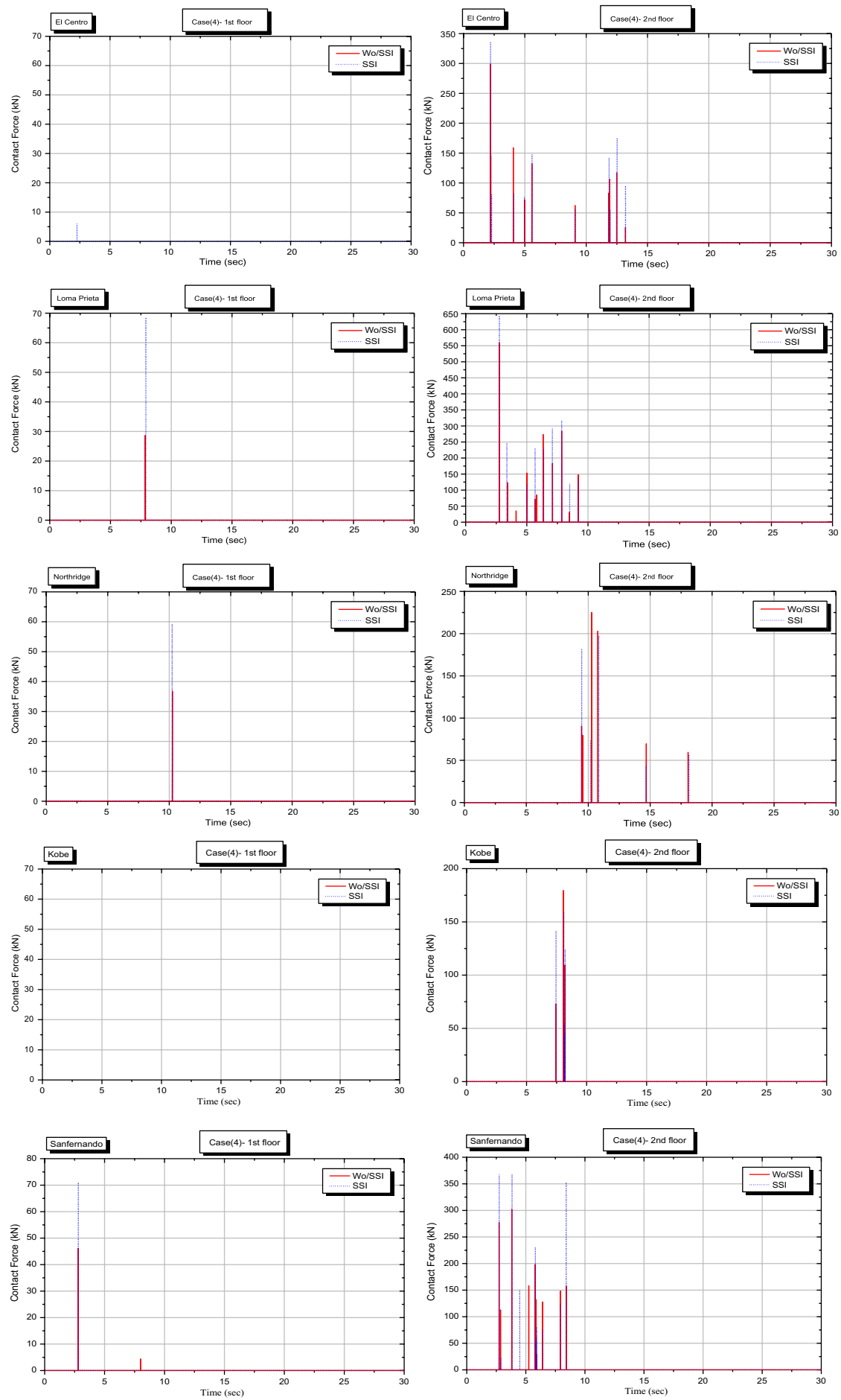

Fig. 27 Pounding force at the first and second stories for Case (4) with $3 \mathrm{~cm}$ gap distance 


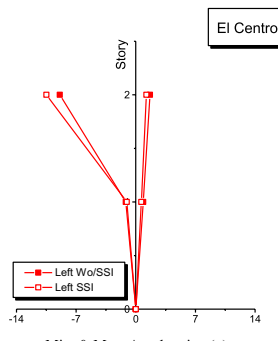

Min. \& Max. Acceleration (g)

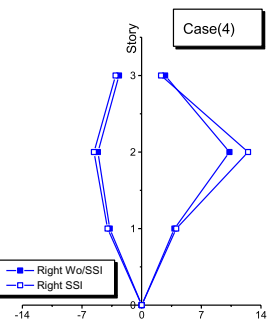

Min. \& Max. Acceleration (g)
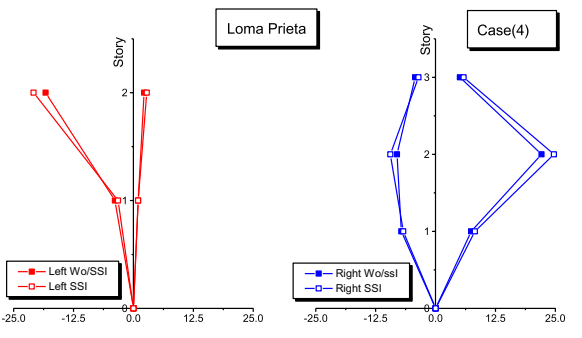

Min. \& Max. Acceleration (g)

Min. \& Max. Acceleration (g)

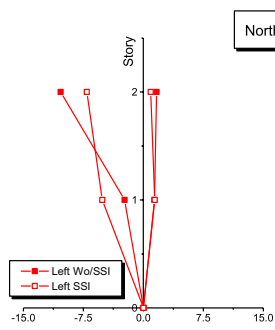

Min. \& Max. Acceleration (g)
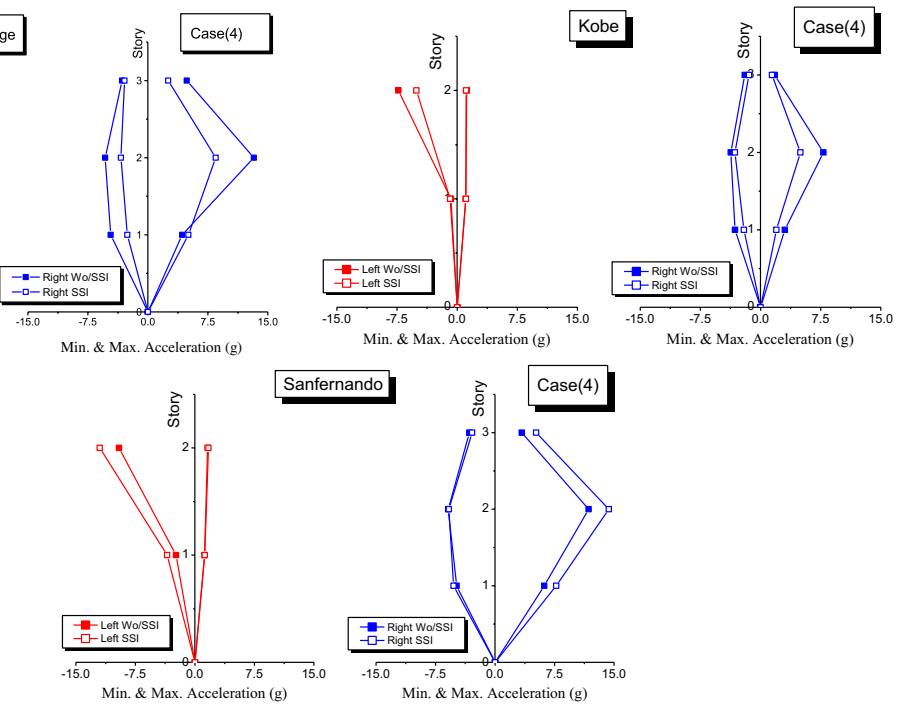

Fig. 28 Peak accelerations for the pounding-involved Case (4) with $3 \mathrm{~cm}$ gap distance

soil flexibility increased the peak strains in some cases and decreased them in other cases without specific trend.

Figure 31 shows the strain time history of the equivalent strut of the right building under the effect of the Northridge earthquake. When the flexibility of the soil is ignored, the strain in the brick exceeded the elastic limit by 1.30 times and plastic strain was observed. On the other hand, incorporation of the soil flexibility in the analysis decreased the strain in the infill by $45.90 \%$ and no plastic strain was observed. It is worth mentioning that no plastic strain was observed in the brick under the effect of the other earthquakes.

\subsubsection{Different seismic gap distances}

Table 8 shows the effect of considering soil flexibility for Case (4) with different gap distances. It can be observed that increasing or decreasing the gap distance results in an increase or reduction of the acceleration or displacement responses without a specific trend. The maximum reduction in the acceleration response reached $73.89 \%$ at the 2 nd floor of the right building under the Northridge earthquake with $5 \mathrm{~cm}$ gap distance; whereas the maximum increase reached $296.57 \%$ at the 1 st floor of the left building under the effect of Northridge earthquake with $1 \mathrm{~cm}$ gap distance. Moreover, the maximum reduction in 

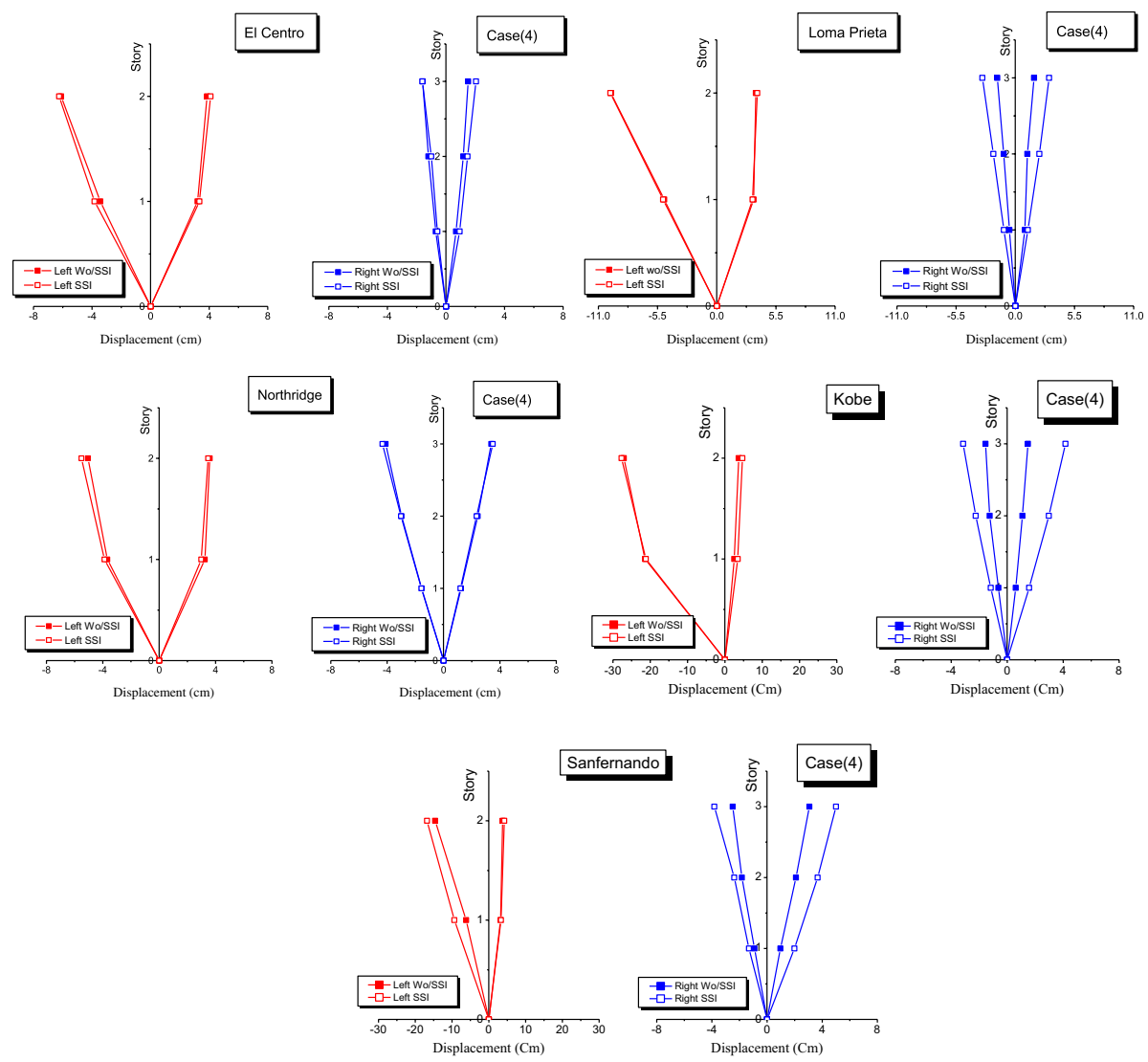

Fig. 29 Peak displacements for the pounding-involved Case (4) with $3 \mathrm{~cm}$ gap distance

the displacement response reached $30.52 \%$ at the 2 nd floor of the left building under the Northridge earthquake with $1 \mathrm{~cm}$ gap distance. The maximum increase in the displacement response reached $168.58 \%$ at the $3 \mathrm{rd}$ story of the right building with $3 \mathrm{~cm}$ gap distance under the Kobe earthquake.

The maximum pounding force reached $796 \mathrm{kN}$ at the second floor with flexible base under the Loma Prieta earthquake and $1 \mathrm{~cm}$ gap distance. The maximum increase in the strain of the steel columns reached $69.19 \%$ for the right building under the Kobe earthquake with $3 \mathrm{~cm}$ gap distance and the maximum reduction reached $39.8 \%$ for the right building under the Northridge earthquake and $3 \mathrm{~cm}$ gap distance where the building essentially responded in the elastic stage. The strain in the infill of the right building was reduced by $45.9 \%$ under the Northridge earthquake with $3 \mathrm{~cm}$ gap distance and increased by $27.3 \%$ under the Kobe earthquake for $3 \mathrm{~cm}$ gap distance. Generally speaking, increasing or decreasing the gap distance may lead to an increase or decrease in the response of the adjacent buildings without any specific trend. 

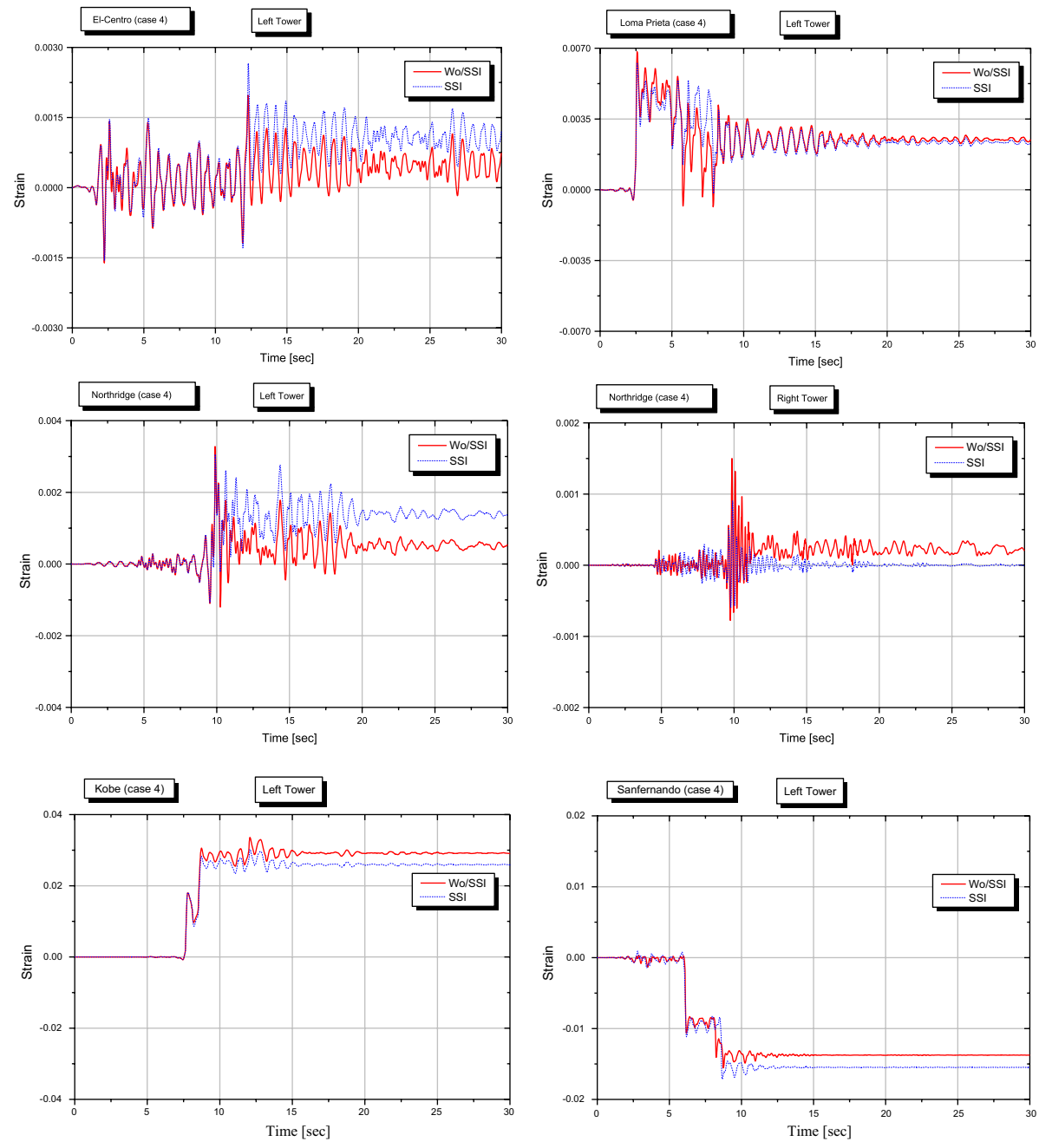

Fig. 30 Strain time history of the steel frame columns for Case (4) with $3 \mathrm{~cm}$ gap distance

\section{Conclusions}

The contribution of the soil flexibility and the influence of masonry infill, on the seismic response of adjacent colliding steel frame buildings have been studied. Nonlinear finite element analyses for two adjacent multi-story structures with four different configurations have been performed. The results of the study reveal that:

1. For the bare frames cases, considering SSI slightly increased the natural periods of buildings. As a result, it caused minor increase in the peak displacement (by about 15\%) associated with minor reduction in the peak acceleration, as compared to the rigid base case. This effect complies with NEHRP (2012) recommendations where the structureto-soil stiffness ratio of the bare frame is $\mathrm{h} /\left(\mathrm{V}_{\mathrm{s}} \mathrm{T}\right)=0.063$ which is less than 0.1 meaning 


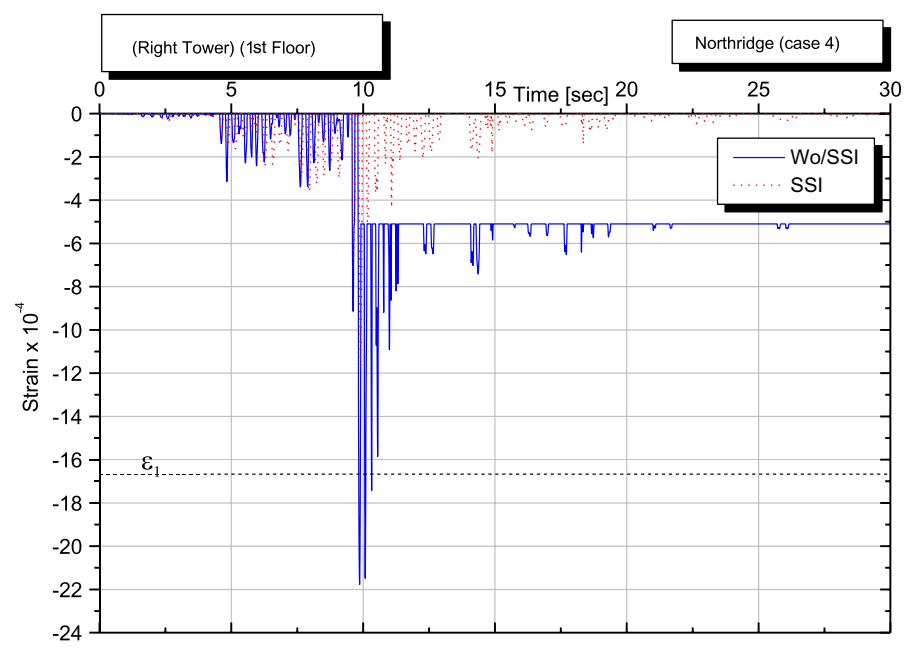

Fig. 31 Strain time history of the equivalent strut for the right building for Case (4) under the Northridge earthquake with $3 \mathrm{~cm}$ gap distance

that no significant lengthening of the natural period will occur and, consequently, no significant difference in the seismic behavior will take place. It should be emphasized, however, that this criteria is valid only for the independent vibrations of buildings and the contribution of pounding changes this rule.

2. The comparison between pounding-involved and independent vibrations of bare frame buildings considering the SSI clearly indicated that pounding significantly affects the response of both structures. It increased the peak acceleration of the colliding buildings by ratios in the range of 11-27 times, as compared to the no pounding case.

3. Comparing the pounding-involved responses for rigid and flexible base bare frames (Case 1) reveals that considering SSI reduces the inelastic response of buildings. Moreover, it has a considerable effect leading to the decrease in the ductility demand for most cases. For instance, under the effect of the Northridge earthquake, local failure of the steel column of the 2 nd floor of the left building at point located directly under the impacted surface was observed for the rigid base case. The strain in this point significantly exceeded the ultimate strain. On the other hand, considering the soil flexibility decreased the strain significantly. Moreover, considering the soil flexibility has a considerable effect on the pounding force by increasing or decreasing it with no specific trend.

4. For the fully infilled frames, the contribution of the soil flexibility significantly increased the natural periods, as compared to the rigid base case. This greatly altered the seismic response of the independent vibrations of buildings depending on the location of the shifted period on the response spectrum curve for each specific earthquake.

5. For the fully infilled frames with rigid base, no collisions between buildings were observed and the structures vibrated independently during different earthquakes. This is attributed to the limited displacement values due to the existence of infill. On the other hand, taking SSI into consideration increases the overall flexibility of both buildings. It shifts the natural period and hence increases the displacements. If the increased displacements result in collisions, significant increase in the acceleration values at the locations of collisions takes place. 
6. The results obtained for the studied cases generally emphasize that ignoring the contribution of the soil flexibility and the effect of the infill panels may significantly alter the behavior of adjacent structures. This may result in a wrong expectation of the seismic response of buildings under earthquake excitation.

Open Access This article is distributed under the terms of the Creative Commons Attribution 4.0 International License (http://creativecommons.org/licenses/by/4.0/), which permits unrestricted use, distribution, and reproduction in any medium, provided you give appropriate credit to the original author(s) and the source, provide a link to the Creative Commons license, and indicate if changes were made.

\section{References}

Abdel Raheem SE (2006) Seismic pounding between adjacent building structures. Electron J Struct Eng 6:66-74

ADINA R\&D, Inc. (2010) Automatic dynamic incremental nonlinear analysis. Reference manual

AISC 360-10 (2010) Specification for structural steel buildings

Anagnostopoulos SA (1988) Pounding of buildings in series during earthquakes. Earthq Eng Struct Dyn $16: 443-456$

Anagnostopoulos SA, Spiliopoulos KV (1992) An investigation of earthquake induced pounding between adjacent buildings. Earthq Eng Struct Dyn 21:289-302

Bathe KJ, Chaudhary AA (1985) Solution method for planar and axisymmetric contact problems. Int J Numerical Methods Eng 21:65-88

Beskos DE, Krauthammer T, Vardoulakis IG (eds) (1994) Dynamic soil-structure interaction. Balkema A.A. Publishers, Rotterdam

Bowles J (1997) Foundation analysis and design. McGraw-Hill Book Co, Singapore. ISBN 0-07-912247-7

Chouw N, Hao H (2005) Study of SSI and non-uniform ground motion effect on pounding between bridge girders. Soil Dyn Earthq Eng 25:717-728

Chouw N, Hao H (2008) Significance of SSI and nonuniform near-fault ground motions in bridge response I: effect on response with conventional expansion joint. Eng Struct 30:141-153

Demir F, Sivri M (2002) Earthquake response of masonry infilled frames. In: ECAS2002 international symposium on structural and earthquake engineering, Ankara, Turkey, pp 151-158

Dorji J, Thambiratnam DP (2009) Modelling and analysis of infilled frame structures under seismic loads. Open Constr Build Technol J 3:119-126

El-Dakhakhni WW, Hamid AA, Elgaaly M (2004) Strength and stiffness prediction of masonry infill panels. In: 13th world conference on earthquake engineering, Vancouver, BC, Canada, 1-6 August, 2004, paper no. 3089

El-Khoriby S, Seleemah A, Jankowski R, Elwardany H (2015a) Experimental and numerical study on pounding of structures in series. In: Matsagar V (ed) Advances in structural engineering. Springer, Berlin

El-Khoriby S, Seleemah A, Elwardany H, Jankowski R (2015b) Influence of earthquake-induced pounding on response of adjacent structures in series: experimental and numerical study. In: International conference on advances in structural and geotechnical engineering, ICASGE'15, Hurgada, Egypt, 6-9 April

Elwardany H, Seleemah A, Jankowski R (2017) Seismic pounding behavior of multi-story buildings in series considering the effect of infill panels. Eng Struct 144:139-150

Eurocode 3 (EN1993-1-5) (2006) Design of steel structures-part 1-5: plated structural elements, EN 19931-5:2006, incorporating corrigendum

Favvata MJ, Karayannis CG (2013) The inter-story pounding effect on the seismic behavior of infilled and pilotis RC structures. In: Proceedings of the 6th European workshop on the "seismic behaviour of irregular and complex structures" Haifa, 12-13 September 2011. Paper no. 38. Geotechnical, geological and earthquake engineering, vol 24, pp 87-101

Favvata MJ, Karayannis CG, Liolios AA (2009) Influence of exterior joint effect on the inter-story pounding interaction of structures. J Struct Eng Mech 33(2):113-136 
Favvata MJ, Karayannis CG, Anagnostopoulou V (2012) Influence of infill panels with and without openings on the pounding effect of RC structures. In: Proceedings of 15th world conference on earthquake engineering, Lisbon, Portugal, 24-28 September 2012. Paper no. 3647

FEMA 273 (1997) Guidelines for the seismic rehabilitation of buildings

FEMA 356 (2000) Prestandard and commentary for the seismic rehabilitation of buildings

Gazetas G (1991) Formulas and charts for impedances of surface and embedded foundations. J Geotech Eng 117(9):1363-1381

Jankowski R (2005) Impact force spectrum for damage assessment of earthquake-induced structural pounding. Key Eng Mater 293-294:711-718

Jankowski R, Mahmoud S (2015) Earthquake-induced structural pounding. Springer, Cham. ISBN 978-3-319-16323-9

Jankowski R, Mahmoud S (2016) Linking of adjacent three-storey buildings for mitigation of structural pounding during earthquakes. Bull Earthq Eng 14(11):3075-3097

Jankowski R, Seleemah A, El-Khoriby S, Elwardany H (2015) Experimental study on pounding between structures during damaging earthquakes. Key Eng Mater 627:249-252

Karayannis CG, Favvata MJ (2005a) Inter-story pounding between multistory reinforced concrete structures. Struct Eng Mech 20(5):505-526

Karayannis CG, Favvata MJ (2005b) Earthquake-induced interaction between adjacent reinforced concrete structures with non-equal heights. Earthq Eng Struct Dyn 34(1):1-20

Karayannis CG, Kakaletsis DJ, Favvata MJ (2005) Behavior of bare and masonry infilled R/C frames under cyclic loading: experiments and analysis. Earthq Resist Eng Struct 81:429-438

Karayannis CG, Favvata MJ, Kakaletsis DJ (2011) Seismic behaviour of infilled and pilotis RC frame structures with beam-column joint degradation effect. Eng Struct 33(10):2821-2831

Kharazian A (2017) Analysis of seismic pounding of moderate height RC buildings with aligned slabs. Doctoral dissertation, Technical University Catalonia

Li P, Liu S, Lu Z (2017) Studies on pounding response considering structure-soil-structure interaction under seismic loads. Sustainability 9:2219

Madani B, Behnamfar F, TajmirRiahi H (2015) Dynamic response of structures subjected to pounding and structure-soil-structure interaction. Soil Dyn Earthq Eng 78:46-60

Mahmoud S, Abd-Elhamed A, Jankowski R (2013) Earthquake-induced pounding between equal height multi-storey buildings considering soil-structure interaction. Bull Earthq Eng 11:1021-1048

Maison BF, Kasai K (1992) Dynamics of pounding when two buildings collide. Earthq Eng Struct Dyn 21(9):771-786

Miari M, Choong KK, Jankowski R (2019) Seismic pounding between adjacent buildings: identification of parameters, soil interaction issues and mitigation measures. Soil Dyn Earthq Eng 121:135-150

Minasidis G, Hatzigeorgiou GD, Beskos DE (2014) SSI in steel frames subjected to near-fault earthquakes. Soil Dyn Earthq Eng 66:56-68

Mulliken JS, Karabalis DL (1998) Discrete model for dynamic through-the-soil coupling of 3D foundations and structures. Earthq Eng Struct Dyn 27:687-710

Naderpour H, Barros RC, Khatami SM, Jankowski R (2016) Numerical study on pounding between two adjacent buildings under earthquake excitation. Shock Vib 2016:1504783

NEHRP (2012) Soil-structure interaction for building structures. Prepared for U.S Department of Commerce National Institute of Standards and Technology Engineering Laboratory Gaithersburg, MD 20899. By NEHRP consultants joint venture a partnership of the applied technology council and the consortium of universities for research in Earthquake engineering. NIST GCR 12-917-21

Nwofor TC (2012) Shear resistance of reinforced concrete infilled frames. Int J Appl Sci Technol 2(5): $148-163$

Papadrakakis M, Apostolopoulou C, Zacharopoulos A, Bitzarakis S (1996) Three-dimensional simulation of structural pounding during earthquakes. J Eng Mech 122:423-431

Rahman AM, Carr AJ, Moss PJ (2001) Seismic pounding of a case of adjacent multiple-storey buildings of differing total heights considering soil flexibility effects. Bull N Z Soc Earthq Eng 34(1):40-59

Sanij ED, Alaghebandian R (2012) Nonlinear earthquake response analysis of RC frames with masonry infills. In: Proceedings of 15th world conference on earthquake engineering, Lisbon, Portugal, 24-28 September. Paper no. 1499

Shames IH, Cozzarelli FA (1997) Elastic and inelastic stress analysis. Prentice Hall, Englewood Cliffs

Sołtysik B, Jankowski R (2013) Non-linear strain rate analysis of earthquake-induced pounding between steel buildings. Int J Earth Sci Eng 6(3):429-433

UBC (1997) Uniform building code, vol 2

Wakabayashi M (1985) Design of earthquake-resistant buildings. McGraw-Hill, New York

Wolf JP (1985) Dynamic soil-structure interaction. Prentice-Hall Inc, Englewood Cliffs 
Zhang B (2006) Parametric study on the influence of infills on the displacement capacity of RC frames for earthquake loss estimation. Dissertation for the master degree in earthquake engineering, European School for Advanced Studies in Reduction of Seismic Risk

Publisher's Note Springer Nature remains neutral with regard to jurisdictional claims in published maps and institutional affiliations. 